\title{
Regional responses of surface ozone in Europe to the location of high-latitude blocks and subtropical ridges
}

\author{
Carlos Ordóñez $^{1}$, David Barriopedro ${ }^{1,2}$, Ricardo García-Herrera ${ }^{1,2}$, Pedro M. Sousa ${ }^{3}$, and Jordan L. Schnell ${ }^{4,5}$ \\ ${ }^{1}$ Departamento de Física de la Tierra II, Facultad de Ciencias Físicas, Universidad Complutense de Madrid, \\ 28040 Madrid, Spain \\ ${ }^{2}$ Instituto de Geociencias (IGEO, CSIC-UCM), Madrid, Spain \\ ${ }^{3}$ Instituto Dom Luiz, Faculdade de Ciências, Universidade de Lisboa, 1749-016 Lisboa, Portugal \\ ${ }^{4}$ Department of Earth System Science, University of California, Irvine, CA 92697, USA \\ ${ }^{5}$ Program in Atmospheric and Oceanic Sciences, Princeton University, Princeton, NJ 08540, USA \\ Correspondence to: Carlos Ordóñez (carlordo@ucm.es)
}

Received: 17 September 2016 - Discussion started: 28 October 2016

Revised: 24 January 2017 - Accepted: 6 February 2017 - Published: 28 February 2017

\begin{abstract}
This paper analyses for the first time the impact of high-latitude blocks and subtropical ridges on near-surface ozone $\left(\mathrm{O}_{3}\right)$ in Europe during a 15-year period. For this purpose, a catalogue of blocks and ridges over the Euro-Atlantic region is used together with a gridded dataset of maximum daily $8 \mathrm{~h}$ running average ozone $\left(\mathrm{MDA} 8 \mathrm{O}_{3}\right)$ covering the period 1998-2012. The response of ozone to the location of blocks and ridges with centres in three longitudinal sectors (Atlantic, ATL, 30- $0^{\circ} \mathrm{W}$; European, EUR, 0-30 ${ }^{\circ}$ E; Russian, RUS, $30-60^{\circ} \mathrm{E}$ ) is examined. The impact of blocks on ozone is regionally and seasonally dependent. In particular, blocks within the EUR sector yield positive ozone anomalies of $\sim 5-10 \mathrm{ppb}$ over large parts of central Europe in spring and northern Europe in summer. Over 20 and $30 \%$ of the days with blocks in that sector register exceedances of the 90th percentile of the seasonal ozone distribution at many European locations during spring and summer, respectively. The impacts of ridges during those seasons are subtle and more sensitive to their specific location, although they can trigger ozone anomalies above $10 \mathrm{ppb}$ in northern Italy and the surrounding countries in summer, eventually exceeding European air quality (AQ) targets. During winter, surface ozone in the north-west of Europe presents completely opposite responses to blocks and ridges. The anticyclonic circulation associated with winter EUR blocking, and to a lesser extent with ATL blocking, yields negative ozone anomalies between -5 and $-10 \mathrm{ppb}$ over the UK, northern France and the Benelux. Conversely, the enhanced zonal flow around
\end{abstract}

$50-60^{\circ} \mathrm{N}$ during the occurrence of ATL ridges favours the arrival of background air masses from the Atlantic and the ventilation of the boundary layer, producing positive ozone anomalies of $\sim 5 \mathrm{ppb}$ in an area spanning from the British Isles to the northern half of Germany. We also show that multiple linear models on the seasonal frequency of occurrence of these synoptic patterns can explain a considerable fraction of the interannual variability in some winter and summer ozone statistics (mean levels and number of exceedances of the 90th percentile) over some regions of western Europe. Thus, this work provides the first quantitative assessments of the remarkable but distinct impacts that the anticyclonic circulation and the diversion of the zonal flow associated with blocks and ridges exert on surface ozone in Europe. The findings reported here can be exploited in the future to evaluate the modelled responses of ozone to circulation changes within chemical transport models (CTMs) and chemistryclimate models (CCMs).

\section{Introduction}

Air pollution results from a combination of elevated emissions and unfavourable weather conditions. One of the air pollutants of most concern for public health is surface ozone $\left(\mathrm{O}_{3}\right)$. Ozone in the troposphere is formed by photochemical reactions involving non-methane volatile organic compounds (NMVOCs), carbon monoxide (CO) and nitrogen ox- 
ides $\left(\mathrm{NO}_{x} \equiv \mathrm{NO}+\mathrm{NO}_{2}\right)$. The oxidation of methane $\left(\mathrm{CH}_{4}\right)$ also contributes to tropospheric ozone formation at the global scale. Another source of tropospheric ozone is the injection of $\mathrm{O}_{3}$ from the stratosphere, while dry deposition to the Earth's surface and chemical loss provide the main sinks. Ozone is known to be detrimental not only to humans' health (e.g. Brunekreef and Holgate, 2002) but also to ecosystems, reducing plant primary productivity and crop yields (e.g. Ashmore, 2005). Moreover, tropospheric $\mathrm{O}_{3}$ is a greenhouse gas. The past increase in tropospheric $\mathrm{O}_{3}$ is estimated to have contributed $0.40(0.20-0.60,5-95 \%$ confidence interval) $\mathrm{W} \mathrm{m}^{-2}$ to direct radiative forcing (RF) since the preindustrial era (Myhre et al., 2013). There is also robust evidence that tropospheric ozone can reduce the natural uptake of carbon dioxide $\left(\mathrm{CO}_{2}\right)$ by decreasing plant productivity (Sitch et al., 2007), although quantitative estimates of the associated indirect RF are still uncertain (Myhre et al., 2013).

A large number of observational studies have established statistical relationships between near-surface ozone concentrations and meteorological variables at the local and regional scales for over two decades (e.g. Bloomfield et al., 1996; Tarasova and Karpetchko, 2003; Ordóñez et al., 2005; Camalier et al., 2007; Seo et al., 2014). Comprehensive summaries can be found in the reviews by Jacob and Winner (2009) and Fiore et al. (2012, 2015). While ozone is favoured by elevated temperatures and regional stagnation in summer (e.g. Jacob and Winner, 2009), stable weather conditions generally accelerate the loss of ozone close to the surface in winter through the enhanced effect of dry deposition and reaction with nitrogen monoxide (NO) to form nitrogen dioxide $\left(\mathrm{NO}_{2}\right)$, a process known as ozone titration (e.g. Laurila et al., 1999; Ordóñez et al., 2005).

Some studies have addressed the connection of tropospheric ozone with circulation patterns, but the few analyses available for Europe are often restricted to specific regions. As an example, some studies have established objective links between circulation weather types and surface ozone in western Iberia (Carvalho et al., 2010; Russo et al., 2014) as well as in north-western and central Europe (e.g. Demuzere et al., 2009, 2011). Furthermore, past research efforts have traditionally been focused on the export of pollution from North America and the injection of stratospheric ozone into the troposphere (see e.g. Monks et al., 2009, 2015, and references therein) as well as on the impact of the North Atlantic Oscillation (NAO) regimes (Hurrell, 1995; Jones et al., 1997). Creilson et al. (2003) suggested that during positive phases of the NAO, characterized by stronger than usual Azores high and Icelandic low, the enhanced westerlies across the North Atlantic lead to increased springtime ozone in western Europe as a consequence of the long-range transport of pollution plumes from North America. More recently, Pausata et al. (2012) showed that the commonly used NAO index (NAOI) is able to capture the link existing between atmospheric dynamics and European surface ozone concentra- tions in winter and spring, while a modified NAO index is needed to detect the atmospheric circulation-ozone relationship in summer.

Monthly teleconnection indices associated with largescale circulation patterns can explain intra- and interannual fluctuations of the intensity of the zonal flow, but such one-dimensional monthly-based approaches limit our understanding of the complex spatial patterns occurring at intramonthly time scales (e.g. Sousa et al., 2016). Therefore, the day-to-day variability of the $\mathrm{O}_{3}$ concentrations at the regional scale may be better captured by analysing daily circulation indices or the occurrence, persistence and position of specific synoptic-scale weather patterns. For example, some attention has already been paid to the role of frontal passages associated with mid-latitude cyclones as well as to the relative position and strength of meteorological systems in $\mathrm{Eu}-$ rope (e.g. Ordóñez et al., 2005; Doche et al., 2014). During summer, the first days after a frontal passage are usually accompanied by an increase in temperature and stagnation of the air masses, leading to elevated ozone concentrations over central Europe, while the opposite effect can be observed in winter as the stability favours the ozone loss by titration and dry deposition (Ordóñez et al., 2005). The relative position and strength of the Azores anticyclone and Middle Eastern depression (Doche et al., 2014), as well as the subsidence of ozone-rich air masses from the upper troposphere and lower stratosphere (e.g. Doche et al., 2014; Zanis et al., 2014), also influence the variability of lower tropospheric ozone over the Mediterranean in summer. Many studies have highlighted the complexity of the ozone dynamics in the Mediterranean region, where the interaction between the synoptic-scale and mesoscale circulations needs to be considered. A number of sub-synoptic processes such as land-sea breeze and channelling effects due to terrain features which favour the recirculation of air masses and the formation of ozone reservoir layers, vertical mixing along the sloped terrain, and subsidence are known to be relevant in the region (e.g. Millán et al., 2000; Gangoiti et al., 2001; Cros et al., 2004; Drobinski et al., 2007; Flocas et al., 2009; Velchev et al., 2011; Kalabokas et al., 2013). This study will be focused only on the role of the synoptic scale.

Comprehensive analyses of the impact of synoptic patterns on surface ozone in Europe, considering their seasonal effects and temporal scales larger than those of episodic cases, are not common. Among the synoptic features which are expected to impact surface ozone and other air pollutants one can mention the frequency and persistence of highpressure systems with an anticyclonic circulation such as high-latitude blocks and subtropical ridges. These systems are often associated with stable weather conditions in all seasons and above normal temperatures in summer under the anticyclonic centre, thus setting favourable conditions for the formation of ozone in that season. There are conceptual differences in the definition of blocking and subtropical ridge patterns although sometimes they induce sim- 
ilar anomalies in the surface climate (e.g. Barriopedro et al., 2010b; Sousa et al., 2016). Atmospheric blocking is associated with persistent, slow-moving, high-pressure systems that interrupt the prevailing westerly winds of middle and high latitudes and therefore the eastward progress of extratropical storm systems (Christensen et al., 2013). Changes in the frequency and duration of blocking events have a significant impact on temperature and precipitation in winter (Fraedrich et al., 1993; Trigo et al., 2004; Masato et al., 2012; Sousa et al., 2016). Atmospheric blocking has also been associated with temperature extremes in Europe, including heat waves (Matsueda, 2011; Katsafados et al., 2014) and cold spells (Cattiaux et al., 2010; Buehler et al., 2011), presenting stronger links with collocated warm temperature extremes than with collocated cold extremes over mid- to high-latitude land regions (Pfahl and Wernli, 2012). Moreover, subtropical ridges are low-latitude structures characterized by positive geopotential height anomalies extending from subtropical latitudes towards extratropical regions such as southern Europe (e.g. Sousa et al., 2017) and by northward displacements of the North Atlantic eddy-driven jet stream (Woollings et al., 2011). The occurrence of strong and persistent mid-latitude anticyclonic ridges over the eastern North Atlantic plays a key role in triggering severe droughts in western Iberia during winter (Santos et al., 2009a, b). Moreover, Santos et al. (2015) found that temperature extremes in Iberia during summer 2003 were associated with enhanced anticyclonic circulation over northern Africa and the western-central Mediterranean, extending as a ridge towards northern France and diverting the westerly flow to northern Europe. García-Herrera et al. (2010) also showed that the atmospheric conditions during the 2003 "mega-heatwave", which triggered strong air pollution episodes over large areas of western Europe, did not display the typical signatures of canonical blocking patterns. Finally, recent analyses have documented the distinctive regional responses of European temperatures to both blocking and subtropical ridges (Sousa et al., 2017). However, the impact of these synoptic patterns on surface air quality (AQ) on multi-annual time scales has not been assessed yet.

In this study we conduct the first comprehensive analysis of the seasonal impacts of high-latitude blocks and subtropical ridges on near-surface ozone. A recent 15-year gridded dataset of daily ozone mixing ratios over Europe is used for this purpose. Section 2 describes the ozone and meteorological data used as well as the methodology applied to build the catalogue of high-latitude blocks and subtropical ridges. The impact of blocks and ridges on ozone is separately examined for the seasons with the highest levels of this pollutant (spring and summer) in Sect. 3 and winter in Sect. 4. Section 5 investigates whether the occurrence of these synoptic patterns can control the interannual variability of ozone. Finally, Sect. 6 summarises and discusses the main results, while Sect. 7 outlines some of the implications of our findings.

\section{Data and methods}

\subsection{Ozone and meteorological data}

We use an interpolated dataset of observed maximum daily $8 \mathrm{~h}$ running average near-surface ozone $\left(\mathrm{MDA} 8 \mathrm{O}_{3}\right)$ over $\mathrm{Eu}-$ rope during the period 1998-2012. These gridded data have been created with the objective mapping algorithm of Schnell et al. (2014, 2015), who compiled and merged hourly observations from the European Monitoring and Evaluation Programme (EMEP) and the European Environment Agency's air quality database (AirBase) to calculate hourly surface ozone averaged over $1^{\circ} \times 1^{\circ}$ grid cells. This product has been initially used by Schnell et al. $(2014,2015)$ to evaluate global chemical transport models (CTMs) and chemistry-climate models (CCMs). More recently, this dataset has been proved to be useful for the examination of the influence of atmospheric circulation and meteorological conditions on extreme ozone concentrations in Europe (Otero et al., 2016). Overall, seasonal linear trends of MDA8 $\mathrm{O}_{3}$ are small for most regions during the period of analysis. The main exception is the Balkans, which presents significantly positive ozone trends at the $5 \%$ level and will be omitted from the regional analyses presented here.

Daily geopotential heights at $500 \mathrm{hPa}$ (Z500) from the NCEP/NCAR meteorological reanalysis dataset at $2.5^{\circ} \times$ $2.5^{\circ}$ horizontal resolution (Kalnay et al., 1996) are employed for the detection of high-latitude blocks and subtropical ridges (see Sect. 2.2). Daily mean sea level pressure (MSLP) and $850 \mathrm{hPa}$ horizontal wind fields from this reanalysis dataset are also used to compare the low-level flow patterns associated with ridges and blocks and assess their impacts on $\mathrm{MDA} 8 \mathrm{O}_{3}$. Additional meteorological fields such as daily mean total cloud cover, daily mean downward shortwave and longwave radiation fluxes at surface, and temperature at $2 \mathrm{~m}$ (daily mean and daily maximum) have been analysed; we will not show results for these specific fields but they will be discussed when their impact is relevant.

Before introducing the methodology used for the detection of blocks and ridges, we will briefly discuss some of the main climatological features found in the 15 -year MDA8 $\mathrm{O}_{3}$ dataset. This will help interpret the impacts of these synoptic patterns on ozone in the following sections. In this paper seasons are defined as follows: spring (March, April, May; MAM), summer (June, July, August; JJA), autumn (September, October, November; SON) and winter (December, January, February; DJF). For the sake of brevity, autumn will be omitted from our analyses, as $\mathrm{O}_{3}$ mixing rations are not particularly high in this season and the features that blocks and ridges imprint on surface ozone are weaker than those in the other seasons. The reason for this is that during autumn there is a strong transition, with ozone responses to these synoptic patterns in September similar to but smaller in magnitude than those in summer, while in November such responses re- 
semble those of winter, leading to an overall compensation of positive and negative ozone anomalies.

Figure 1 illustrates the seasonal climatology of MDA8 $\mathrm{O}_{3}$ (shaded areas), MSLP (black contour lines) and $850 \mathrm{hPa}$ winds (arrows) in spring (top), summer (middle) and winter (bottom) during the 1998-2012 period. On average over the European continent, surface MDA8 $\mathrm{O}_{3}$ mixing ratios are somewhat higher in spring $(\sim 41 \mathrm{ppb})$ than in summer $(\sim 39 \mathrm{ppb})$. This is not surprising as a distinct spring maximum has been observed at many locations of the Northern Hemisphere. The spring ozone maximum is likely a result of the combination of dynamical processes and photochemistry at relatively unpolluted locations (Monks, 2000), while polluted sites exhibit a double peak or a wide springsummer maximum, with the summer maximum being more pronounced at daytime and hence attributed to photochemical processes (Monks et al., 2015). Observational studies have also shown that the Mediterranean region presents a marked summertime ozone maximum (e.g. Richards et al., 2013, and references therein). Actually, in summer there is a strong north-south gradient, with low mixing ratios in the UK and most of Scandinavia and high in southern Europe, including the areas around the Mediterranean coast (Fig. 1, middle). During this season, ozone levels in northern (central-southern) Europe are lower (higher) than those registered in spring. The highest MDA8 $\mathrm{O}_{3}$ mixing ratios in summer (average seasonal values above $55 \mathrm{ppb}$ ) are found for the Po Basin, where very high levels of ozone and other photooxidants both at the surface and within the boundary layer have been reported in previous field experiments (e.g. Martilli et al., 2002; Neftel et al., 2002; Thielmann et al., 2002; Steinbacher et al., 2005; Liu et al., 2007). The picture in winter is completely different as the European continent is predominantly a sink for ozone during this season (Laurila, 1999). Cold temperatures, low radiation and short days in winter inhibit ozone formation, while shallow mixing layers favour the accumulation of pollutants close to the surface and therefore the depletion of surface ozone by reaction with NO as well as dry deposition. The bottom panel of Fig. 1 shows the low winter ozone levels over most of the continent, in particular in regions of elevated emissions such as the Benelux and the Po Basin. Winter surface ozone presents the highest levels over the northern and western coasts as these are directly under the influence of maritime air masses into the European continent advecting background ozone, which has undergone relatively low loss by dry deposition and photochemical processes. This is favoured by the zonal westerly flow prevailing over northern Europe, as can be inferred from the MSLP and wind fields in the figure.

\subsection{Climatology of high-latitude blocks and subtropical ridges}

We use the same catalogue of high-latitude blocks and subtropical ridges as Sousa et al. (2016, 2017). As mentioned
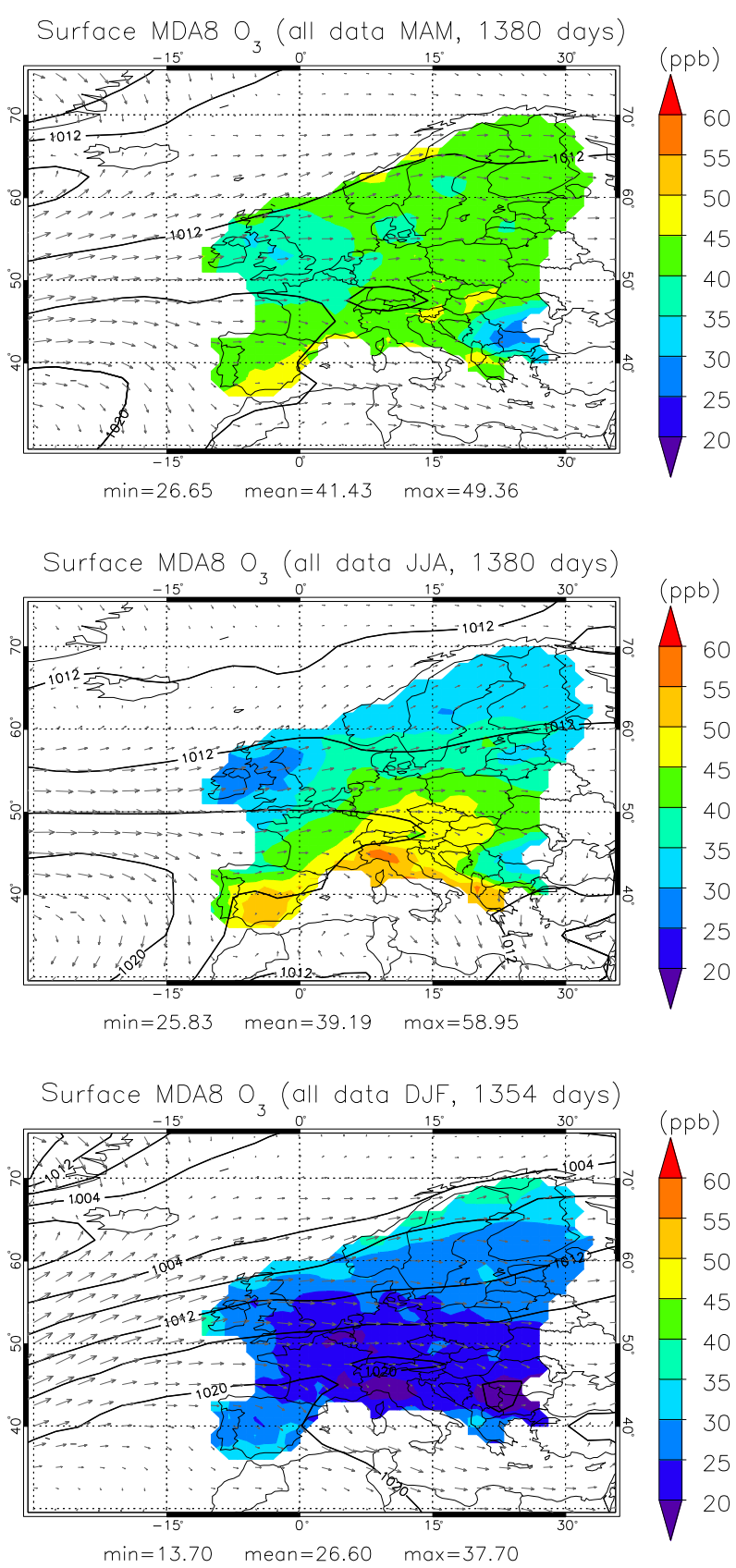

Figure 1. Composites of the seasonal means of maximum daily $8 \mathrm{~h}$ running average near-surface ozone $\left(\mathrm{MDA} 8 \mathrm{O}_{3}\right.$ ) expressed in parts per billion by volume (ppb, shaded areas) in spring (top), summer (middle) and winter (bottom) during the 1998-2012 period. The black contour lines depict the mean sea level pressure (MSLP) for the same period, expressed in $\mathrm{hPa}$. Arrows indicate horizontal winds at $850 \mathrm{hPa}$. The total number of days considered is indicated on the top of each panel. 


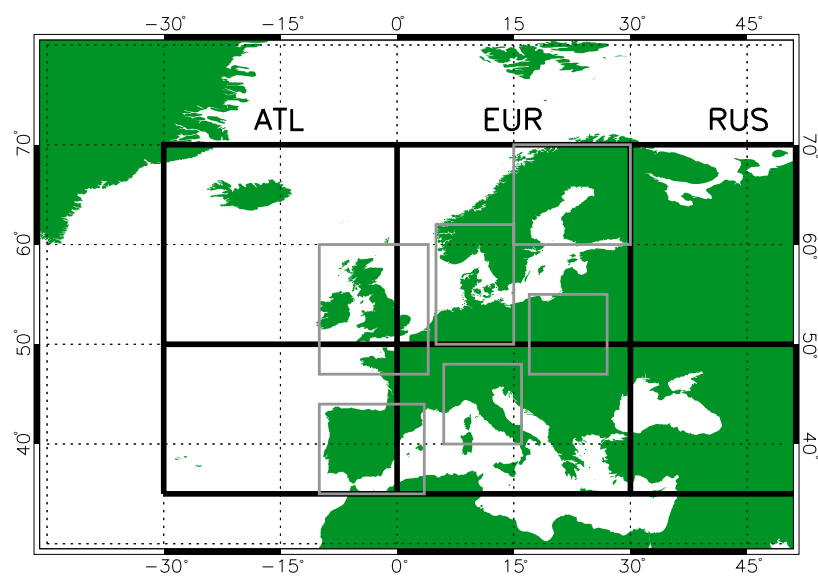

Figure 2. Longitudinal sectors considered for the identification of the centres of high-latitude blocks (northern black boxes) and subtropical ridges (southern black boxes): Atlantic (ATL, 30- $0^{\circ} \mathrm{W}$ ), European (EUR, 0-30 ${ }^{\circ}$ E) and Russian (RUS, 30-60 ${ }^{\circ}$ E, only partially shown). Grey boxes identify the geographic areas considered in the regional assessment performed in Sects. 3 and 4. The regions considered, from west to east and from north to south, are "UK/North Fr", "Central/North EU", "NE Scandinavia", "Iberia", "Central/South EU" and "East EU".

above, the NCEP/NCAR meteorological reanalysis dataset at $2.5^{\circ} \times 2.5^{\circ}$ has been used to create the catalogue. This horizontal resolution is coarser than that of other reanalysis datasets, but it is appropriate to characterise large-scale phenomena such as blocks and ridges. Blocks are detected by applying a simplified version of the method described by Barriopedro et al. (2006), where they are defined as largescale reversals of the Z500 meridional gradient and must fulfil some conditions on area overlap during consecutive days and minimum duration. For this study we have considered that reversals must have a minimum longitudinal extension of $12.5^{\circ}$ during their whole lifetime and a minimum duration of 5 days. To identify ridges and avoid their overlap with blocks, the detection algorithm sets some north/south boxes (black squares in Fig. 2) whose latitudinal limits move according to the season (e.g. the maximum latitude for the detection of ridges is $45^{\circ} \mathrm{N}$ in winter and $50^{\circ} \mathrm{N}$ in summer). The optimal latitudinal break relies on previous work about winter climatologies of ridges in the eastern Atlantic (Santos et al., 2009b) and subsequent sensitivity analyses to calibrate their seasonal frequencies in the area of study (Sousa et al., 2017). Two conditions are imposed for the detection of subtropical ridges: a ridge is detected in a south box if (i) at least $75 \%$ of the grid points are above the 80th percentile of the specific 31-day moving average Z500 climatology during the period 1950-2012 and (ii) no more than 50\% of the grid points of the north box are above the same threshold.

Three longitudinal sectors of $30^{\circ}$ width with two boxes each (north/south) are used to catalogue high-latitude blocks and subtropical ridges regionally according to the position
Table 1. Total number of days with blocking centres identified over each sector (Atlantic, ATL, 30- $0^{\circ} \mathrm{W}$; European, EUR, 0-30 ${ }^{\circ} \mathrm{E}$; Russian, RUS, $30-60^{\circ} \mathrm{E}$ ) and season (winter, DJF: December, January, February; spring, MAM: March, April, May; summer, JJA: June, July, August; autumn, SON: September, October, November) during the 5479 days of the 1998-2012 period.

\begin{tabular}{lrrr|r}
\hline & ATL & EUR & RUS & Total \\
\hline DJF & 228 & 151 & 75 & 454 \\
MAM & 200 & 203 & 131 & 534 \\
JJA & 27 & 91 & 165 & 283 \\
SON & 103 & 169 & 93 & 365 \\
\hline Total & 558 & 614 & 464 & 1636 \\
\hline
\end{tabular}

Table 2. As Table 1 but for ridges.

\begin{tabular}{lrrr|r}
\hline & ATL & EUR & RUS & Total \\
\hline DJF & 204 & 199 & 176 & 579 \\
MAM & 160 & 192 & 156 & 508 \\
JJA & 184 & 189 & 217 & 590 \\
SON & 161 & 165 & 142 & 468 \\
\hline Total & 709 & 745 & 691 & 2145 \\
\hline
\end{tabular}

of their centres (Fig. 2): Atlantic (ATL, 30- $0^{\circ} \mathrm{W}$ ), European (EUR, $0-30^{\circ} \mathrm{E}$ ), and Russian (RUS, $30-60^{\circ} \mathrm{E}$ ). Note that some blocks and ridges can have their centres in more than one sector during their lifetimes, since they tend to move eastwards. Therefore, the use of specific longitudinal sectors is useful to assess how the location of blocking and ridge centres as well as their residence times impact ozone over different areas of the European continent. The total number of days in which block and ridge centres have been identified over each sector and season are displayed in Tables 1 and 2, respectively. As more than one block and ridge can be simultaneously identified within different sectors on the same day, the total number of days with blocks and ridges in the region of study does not coincide with the totals shown in the tables. During the 5479 days of the 1998-2012 period, we have computed a total number of 1609 days with at least one block in any of the three sectors, 1771 days with ridges, and 3050 with blocks and/or ridges. Therefore, more than half the days register at least the occurrence of a block or a ridge anywhere in the whole region. The interannual variability of the number of days with blocks and ridges over a given sector can be rather large, as shown in Supplement Fig. S1.

The seasonal composites of daily Z500 anomalies (with respect to the climatology) and absolute values, considering days with blocking and ridge centres in each sector for a $\sim 60$-year period, can be found in Sousa et al. $(2016,2017)$. For illustration purposes, only the composites of daily Z500 for block and ridge centres over the EUR sector during the 1998-2012 period are shown in Fig. 3, while Figs. S2 and S3 

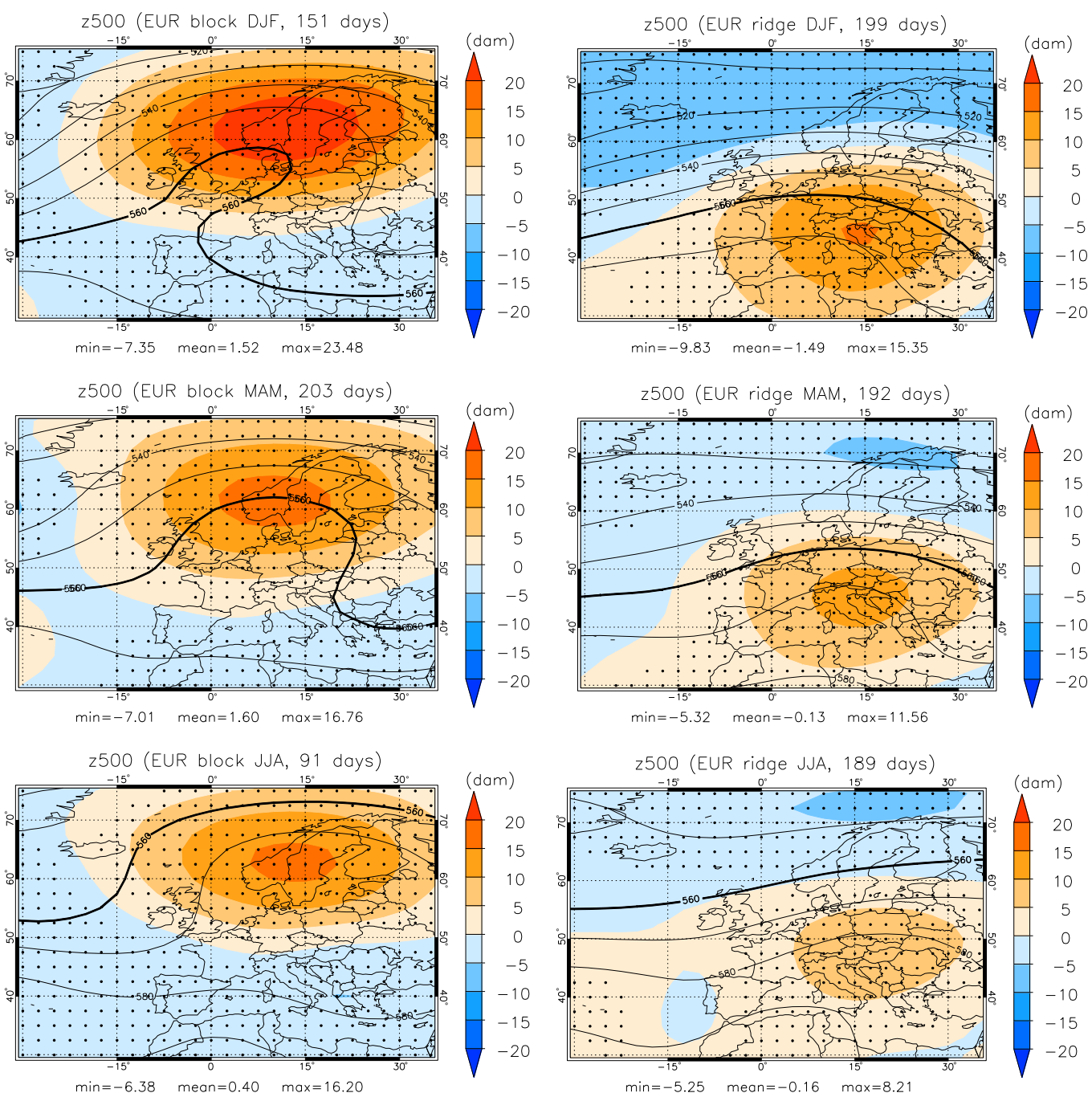

Figure 3. Composites of the daily anomalies with respect to the 1998-2012 climatology (shaded areas) as well as absolute values (black contour lines) of $500 \mathrm{hPa}$ geopotential height (Z500) for blocking (left) and ridge (right) centres within the European sector in winter (top), spring (middle) and summer (bottom). Stippling indicates statistically significant anomalies at the $5 \%$ level (two-sided $t$ test). All values are in decametres (dam) and the thick line represents the 560 dam isohypse. The total number of days considered is indicated on the top of each panel.

display the results for the ATL and RUS sectors, respectively. Stippling indicates statistically significant anomalies at the $5 \%$ level (two-sided $t$ test). The highest values of the absolute Z500 field (black contour lines) and the positive Z500 anomalies (shaded areas) are centred in the respective sector. Significantly positive anomalies dominate the northern latitudes in the case of blocks and the low latitudes in the case of ridges, being the largest found for blocks as well as in winter for all sectors. Another feature that can be seen on the plots is the northward displacement of the atmospheric circulation from spring to summer, as indicated by the position of the 560 dam isohypse in those seasons (thick back contour lines).

\subsection{Data analysis}

Some of the analyses in the following sections are also based on seasonal composites of MDA8 $\mathrm{O}_{3}$ over Europe. For each season, composite differences are calculated between days with blocks or ridges whose centres are in a specific sector (ATL, EUR or RUS) and days without blocks or ridges in that sector. Moreover, to better quantify the impact of blocks and ridges on key European regions, probability density functions (PDFs) of MDA8 $\mathrm{O}_{3}$ have been computed for the grid cells within the grey boxes in Fig. 2 (from west to east and from north to south: "UK/North Fr", "Central/North EU", "NE Scandinavia", "Iberia", "Central/South EU" and "East EU") under different weather regimes. The PDF plots 

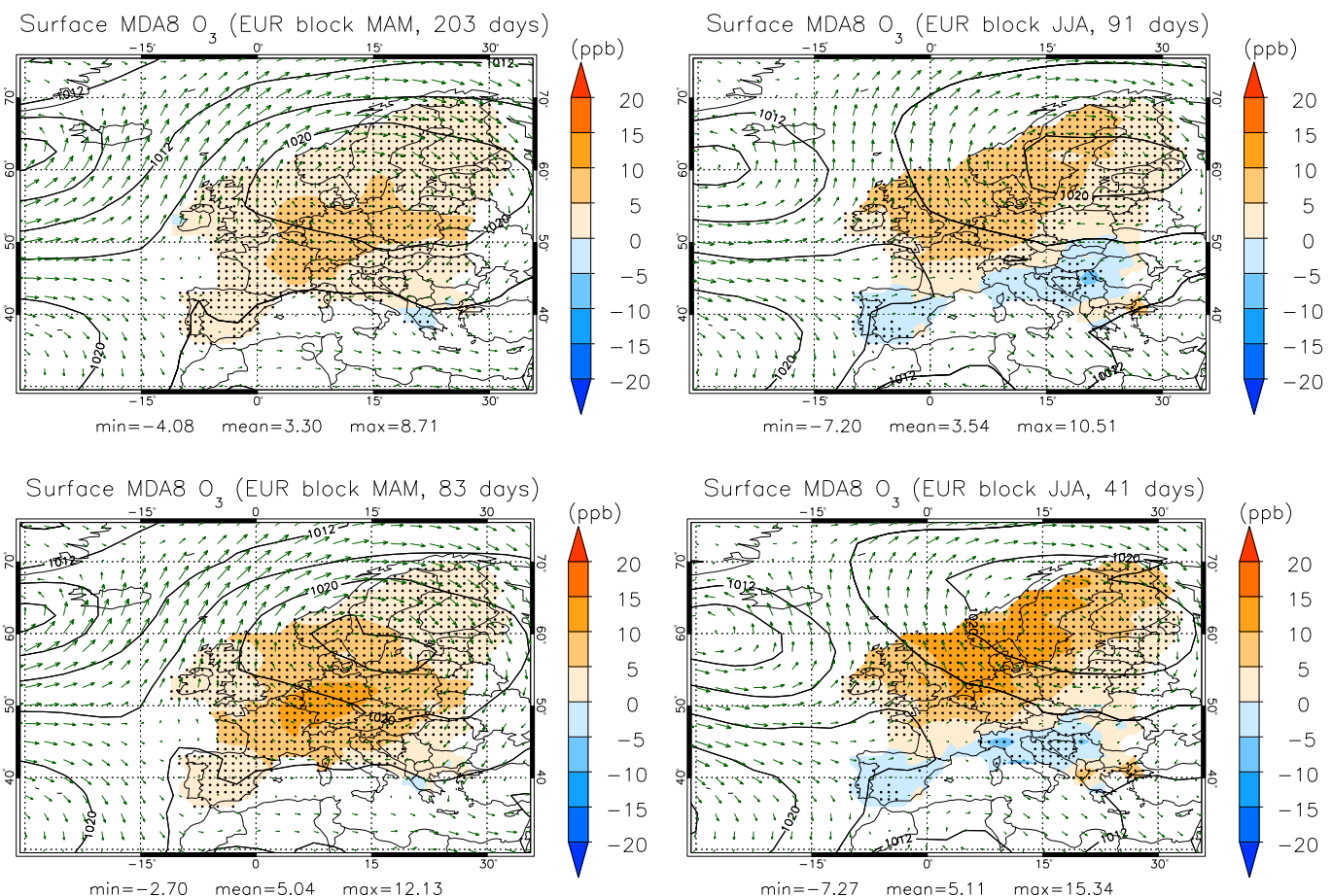

Figure 4. Composites of the seasonal anomalies of surface MDA8 $\mathrm{O}_{3}$ (ppb) for days with blocking centres over the European sector (EUR, $0-30^{\circ} \mathrm{E}$ ) during spring (left) and summer (right). Anomalies have been calculated with respect to the MDA8 $\mathrm{O}_{3}$ mixing ratios on days without EUR blocking in that season during the 1998-2012 period. All data on days with blocking centres remaining over 0-30 ${ }^{\circ} \mathrm{E}$ (top) and data only from the third day with blocks in that sector (bottom) have been taken into account for the calculation of the ozone anomalies. Stippling indicates statistically significant anomalies at the $5 \%$ level (two-sided $t$ test). The black contour lines depict the composites of MSLP (hPa) for those days. Horizontal wind fields at $850 \mathrm{hPa}$ are displayed by arrows. The total number of days considered is indicated on the top of each panel.

will display ozone data in a given region and season, separately for the whole 1998-2012 climatology and for the days with blocks and ridges in each of the three sectors. The twosample Kolmogorov-Smirnov test (two sample K-S test; see e.g. Wilks, 2011) has been used to determine whether the distributions of the daily $\mathrm{O}_{3}$ mixing ratios averaged over such regions on days with blocks and ridges differ from those of the seasonal climatology; we will discuss the situations when the distributions are statistically significant at the $0.1 \%$ level, which may seem too stringent but ensures that only the most relevant changes in the $\mathrm{O}_{3}$ distributions are identified. In addition, to assess the potential implications of blocks and ridges on the occurrence of ozone extremes, days with high ozone extremes are identified locally over each grid cell of the $\mathrm{O}_{3}$ dataset as those when the MDA8 $\mathrm{O}_{3}$ mixing ratios exceed the 90th percentile of the distribution during the corresponding season, while days with low ozone extremes are those below the seasonal 10th percentile. Finally, we have tested some multiple linear regression models in order to quantify to what extent the interannual variability of $\mathrm{O}_{3}$ can be driven by the frequency of occurrence of blocks and ridges.

\section{Impact of high-latitude blocks and subtropical ridges on $\mathrm{MDA8} \mathrm{O}_{3}$ during summer and spring}

\subsection{Regional responses to high-latitude blocks}

First, we focus on the impact of blocks on ozone. From the three $30^{\circ}$ longitude sectors used in this study, blocking over the EUR sector has the strongest impact both in spring and summer. On average for the 15-year period of analysis, MDA8 $\mathrm{O}_{3}$ mixing ratios increase by $5-9 \mathrm{ppb}$ over large areas of central Europe in spring (Fig. 4, upper-left) and by $5-11 \mathrm{ppb}$ over northern Europe in summer (Fig. 4, upperright) on days with EUR blocking, which is broadly consistent with the anticyclonic circulation and continental advection observed over those regions. If in the calculation of the composites we only consider data from the third day blocking centres have stayed over the EUR sector, the extension of the regions with anomalies higher than $5 \mathrm{ppb}$ increases and there are larger areas where they exceed $10 \mathrm{ppb}$ (Fig. 4, bottom panels). This minimum number of 3 days is somewhat arbitrary, but it has been chosen to illustrate that the persistence of blocks over a given area favours the photochemical build-up of $\mathrm{O}_{3}$ both in spring and summer. The strongest pos- 

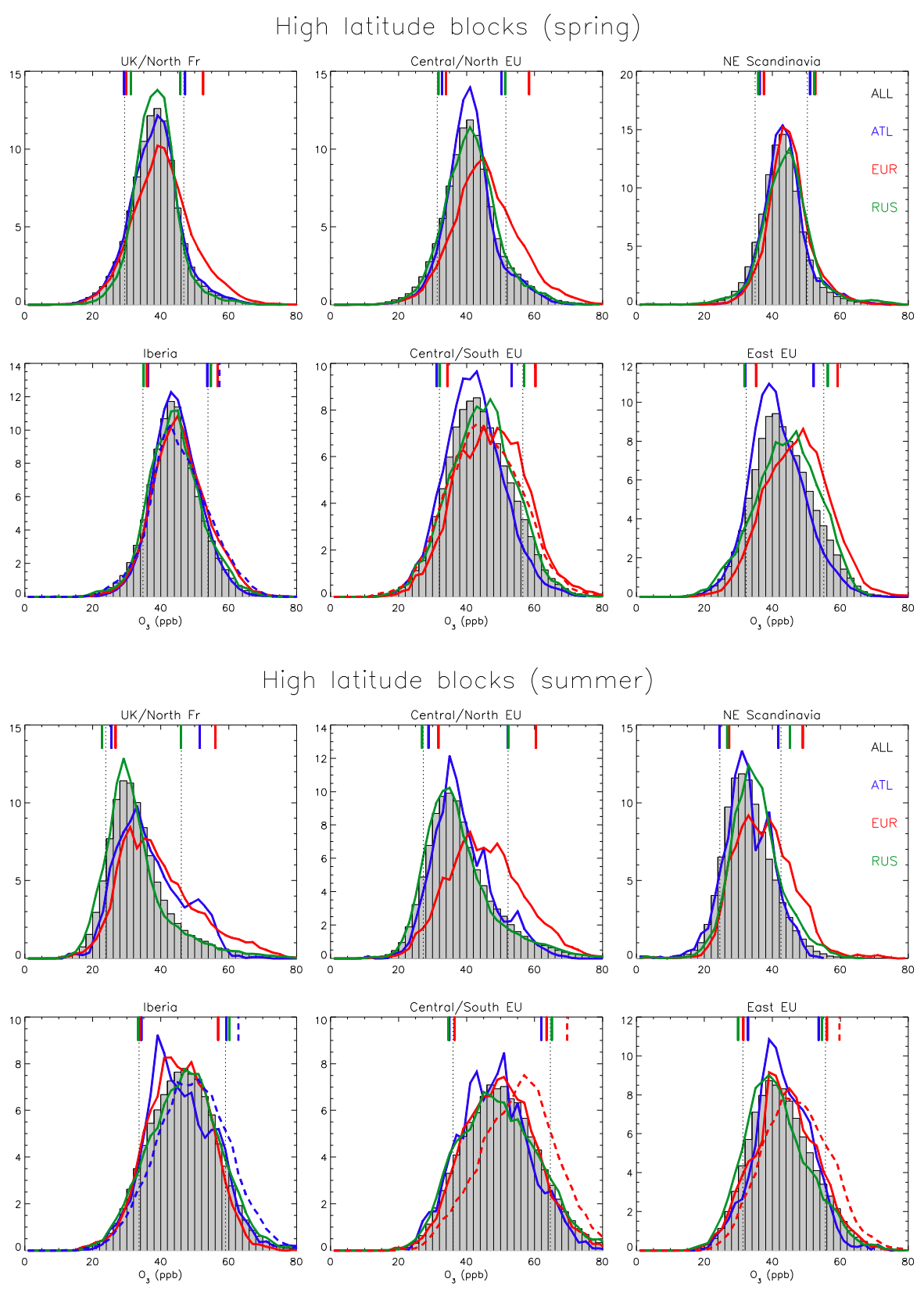

Figure 5. Spring (upper panels) and summer (lower panels) probability frequency distributions (\%) of $\mathrm{MDA}_{8} \mathrm{O}_{3}$ for the six regional boxes presented in Fig. 2 under different synoptic situations. Grey bars denote the 1998-2012 seasonal climatology. Solid lines correspond to days with block centres over the Atlantic (blue), European (red) and Russian (green) sectors. Blue and red dashed lines also represent the frequency distributions of the data when ridge centres are located over the ATL and EUR sectors, respectively; they are only shown for the regions and seasons where surface ozone presents the strongest responses to ridges. The width of the bins is 2 ppb. The horizontal position of the vertical dotted lines represents the 10th and 90th percentiles of the climatology, while the short vertical lines on the top of the plots indicate the values of the 10th and 90th percentiles under the influence of ATL, EUR and RUS blocking. The 90th percentiles of the data with ridges are also displayed as dashed lines when they are above those with blocking.

itive anomalies cover large areas of the continent $\left(40-60^{\circ} \mathrm{N}\right)$ in spring and are located in the north $\left(50-70^{\circ} \mathrm{N}\right)$ during the summer season when weaker negative anomalies are also found in southern Europe. The differences in the latitudinal position of the positive anomalies are due to the northward displacement of the atmospheric circulation from spring to summer. Another factor that might contribute is the fact that the days are long in summer at high latitudes, which would favour the photochemical build-up of ozone under blocking conditions, but further analyses would be needed to corrobo- 
rate this hypothesis. The negative ozone anomalies in southern Europe during summer (right panels of Fig. 4) are associated with increases in cloud cover and $850 \mathrm{hPa}$ wind speed as well as decreases in shortwave radiation and daily maximum temperature over most of this region on days with EUR blocks (not shown).

The PDFs of MDA8 $\mathrm{O}_{3}$ are illustrated in Fig. 5 for both spring (upper panels) and summer (bottom panels). The percentage frequency of all the MDA8 $\mathrm{O}_{3}$ data polled over each region in a given season during the 15 -year period is represented by the grey bars, while data on days with ATL, EUR and RUS blocking are represented by the blue, red and green solid lines, respectively. The vertical dotted lines indicate the 10th and 90th percentiles of the climatology, while the short vertical coloured lines on the top of the plots correspond to the values of the 10th and 90th percentiles for the data under the influence of blocking. Figure 5 highlights the increase in the percentage occurrence of high ozone levels over a number of regions in spring and only over the northern regions in summer on days with EUR blocking (red lines), which is consistent with the results from Fig. 4. The largest increases in the 90th percentile of the ozone volume mixing ratios occur under the influence of EUR blocking for four out of six boxes in spring and for the three northernmost boxes in summer, the differences with the climatology being around 5$10 \mathrm{ppb}$ (compare short solid red lines on top of the panels with the vertical dotted lines). These changes are mainly due to a shift and to some extent also a broadening of the frequency distribution for EUR blocking days. The results from the two-sample $\mathrm{K}-\mathrm{S}$ test reveal that the $\mathrm{O}_{3}$ distribution on days with EUR blocks differs from that of the seasonal climatology (at the $0.1 \%$ level) for all regions except Iberia in spring and for the three northern regions in summer. Another emergent feature is the increase in the occurrence of MDA8 $\mathrm{O}_{3}$ mixing ratios within the range $35-55 \mathrm{ppb}$ over "UK/North Fr" in summer on days with ATL blocking (blue line); however, the two-sample K-S test does not indicate significantly different distributions at the $0.1 \%$ level for this particular case because of the small sample size (only 27 days with ATL blocks in summer, see Table 1). Additional analyses have confirmed that this $\mathrm{O}_{3}$ increase is mainly due to the contribution of days with blocking centres over a narrow longitudinal sector within the east Atlantic $\left(15-0^{\circ} \mathrm{W}\right)$, when the British Isles are under the influence of an anticyclone (Fig. S4). This synoptic situation, albeit relatively uncommon (only 13 days identified in summer during the whole 15-year period), is efficient at increasing ozone in the British Isles and the north-west of France. This is because it is associated with a decrease in cloud cover and therefore an increase in the downward shortwave radiation flux as well as increases in daily maximum temperature and decreases in $850 \mathrm{hPa}$ wind speed over those regions (not shown). There are also weak negative ozone anomalies in southern Europe, in particular over Italy, where the meteorological anomalies are of opposite sign. Overall, RUS blocking does not seem to be closely related to changes in the PDF of ozone for any region.

The previous analyses have illustrated that significant changes in the mean distribution of MDA8 $\mathrm{O}_{3}$ occur mainly in northern and central Europe on days with EUR blocking during summer and spring, respectively. We have also evaluated the evolution of the occurrence of above average $\mathrm{O}_{3}$ mixing ratios and extreme ozone days under the influence of EUR blocking. In particular, during summer the extension of the areas with positive ozone anomalies above $5 \mathrm{ppb}$ increases day after day when block centres are in the EUR sector (Fig. 6). On average for all blocks remaining in that sector, the fifth day registers the maximum anomaly over any given $1^{\circ} \times 1^{\circ}$ cell in the domain $(\sim 23 \mathrm{ppb})$ as well as the maximum extension of anomalies above $5 \mathrm{ppb}$ $\left(\sim 4 \times 10^{6} \mathrm{~km}^{2}\right)$. Moreover, the maximum extension of the areas exceeding the 90th percentile is found for that day as indicated by the grey open squares in the figure. Note, however, that only 7 blocks have been considered for the calculation of anomalies on the fifth day compared to 32 on the first day (see numbers in brackets on the top of the panels); the reason for this is that blocks do not necessarily stay over the same sector during their lifetime. A similar evolution has been found for spring, although the overall magnitude of the anomalies and the total area exceeding the 90th percentile are smaller in that season (not shown).

To better illustrate how EUR blocking impacts the occurrence of extremes in summer and spring, we have calculated the percentage of EUR blocking days with MDA8 $\mathrm{O}_{3}$ values above the 90th percentiles for those seasons. The left panels of Fig. 7 indicate the likelihood that EUR blocking is collocated with exceedances of the 90th percentile in summer (upper left) and spring (lower left). The results at any location can be compared with what would be expected by random chance (i.e. only $10 \%$ of exceedances of the 90th percentile). More than $30 \%$ of the EUR blocking days concur with exceedances of the 90th percentile over large parts of Scandinavia, the North Sea and the north of the UK in summer. Note however that as ozone levels are low in northern Europe during summer (see middle panel of Fig. 1) these events do not often result in exceedances of the EU target value for maximum daily $8 \mathrm{~h}$ mean ozone $\left(120 \mu \mathrm{g} \mathrm{m}^{-3}\right.$, approximately $60 \mathrm{ppb}$; EEA, 2015). The impact is smaller in spring, when $25 \%$ of the EUR blocking days are coincident with exceedances of the 90th percentile over large parts of Germany, north-eastern France, the Benelux and the North Sea. Therefore, EUR blocks increase the occurrence of ozone extremes over some regions mainly in summer but also in spring.

The use of $30^{\circ}$ longitude sectors, as done throughout most of this work, is useful to generalise the interpretation of the impacts of blocks on ozone, but one could expect the occurrence of extremes to be higher for some areas of the continent if we only considered blocks with centres over narrower longitudinal sectors. In fact, the areas with the highest oc- 


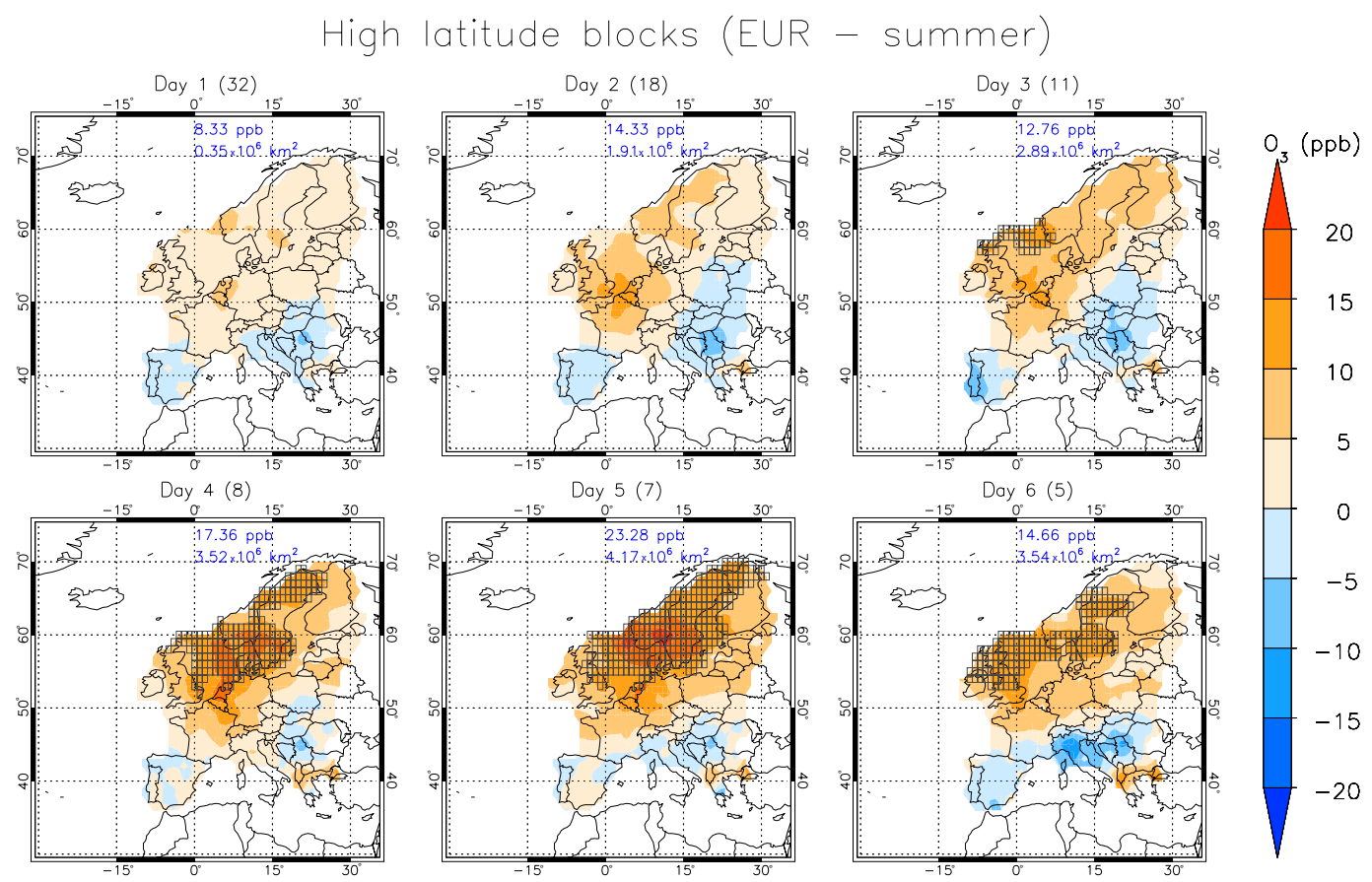

Figure 6. Evolution of MDA8 $\mathrm{O}_{3}$ anomalies under the influence of EUR blocking in summer. The panels show, from left to right and from top to bottom, the average anomalies on the first six days a block is in the sector. The total number of blocks considered is given in brackets on the top of each panel. The maximum anomaly found ( $\mathrm{ppb}$ ) and the total area with anomalies higher than $5 \mathrm{ppb}\left(\mathrm{km}^{2}\right)$ are also indicated in blue colour. Grey open squares indicate grid cells where the ozone composite under blocking exceeds the 90th percentile of the summer distribution.

currence of extremes in the left panels of Fig. 7 move westward/eastward when block centres are considered within the west $\left(0-15^{\circ} \mathrm{E}\right) /$ east $\left(15-30^{\circ} \mathrm{E}\right)$ flanks of the EUR sector and the percentage of occurrence of extremes also increases over those areas (not shown).

\subsection{Regional responses to subtropical ridges}

The impact of subtropical ridges on surface $\mathrm{MDA} 8 \mathrm{O}_{3}$ during spring is considerably smaller than that of blocking for most of the regions considered in this study, while in summer the effect is important for the south and centre of the continent (Fig. S5). Only the most relevant results for regions where the signal of ridges is strong enough are discussed here, separately for spring and summer.

There are two particular cases that stand out in spring: the Iberian Peninsula under the influence of Atlantic ridges and the "Central/South EU" region on days with European ridges. These PDFs are respectively shown for the mentioned boxes as blue and red dashed lines in the upper panel of Fig. 5. In both cases there is an increase in the frequency of events with $\mathrm{MDA} 8 \mathrm{O}_{3}$ above $\sim 50 \mathrm{ppb}$, but the distributions are not significantly different from their corresponding climatological distributions at the $0.1 \%$ level. In the first case, the Azores high moves eastwards and has its centre of action close to Iberia, while in the second case the centre of the anticyclone is located over Italy (not shown). Our findings illustrate that the regional responses of surface ozone to subtropical ridges are generally more localised than those of blocks and hence they are smoothed if large longitudinal sectors are considered for the analyses. Thus, when considering only ridge centres located over a narrower $15^{\circ}$ sector covering the east Atlantic $\left(15-0^{\circ} \mathrm{W}\right.$; see Fig. 8, upper left), the centre of the anticyclone is particularly close to Iberia and the isobaric gradient is stronger than the climatology in the north, yielding moderate positive ozone anomalies of up to $\sim 7$ ppb over Iberia and small negative anomalies in northern Europe. A similar situation, with positive anomalies reaching maximum values of $\sim 8 \mathrm{ppb}$ over northern Italy and extending further into the continent, as well as negative anomalies in northern Europe, is seen for ridges in the west flank of the European sector $\left(0-15^{\circ} \mathrm{E}\right.$; Fig. 8, upper right). In both cases, the relatively small negative ozone anomalies in northern Europe (only up to around $-3 \mathrm{ppb}$ ) are associated with increases in $850 \mathrm{hPa}$ wind speed and cloud cover as well as decreases in shortwave radiation over these regions, while the impact of temperature changes does not seem to be relevant.

In summer, the surface $\mathrm{O}_{3}$ increase over the Iberian Peninsula on days with ATL ridges is stronger than that found for the same synoptic situation in spring (Fig. S5). Nevertheless, the most prominent feature in this season is the shift towards higher values of MDA8 $\mathrm{O}_{3}$ in the PDF for the "Central/South 

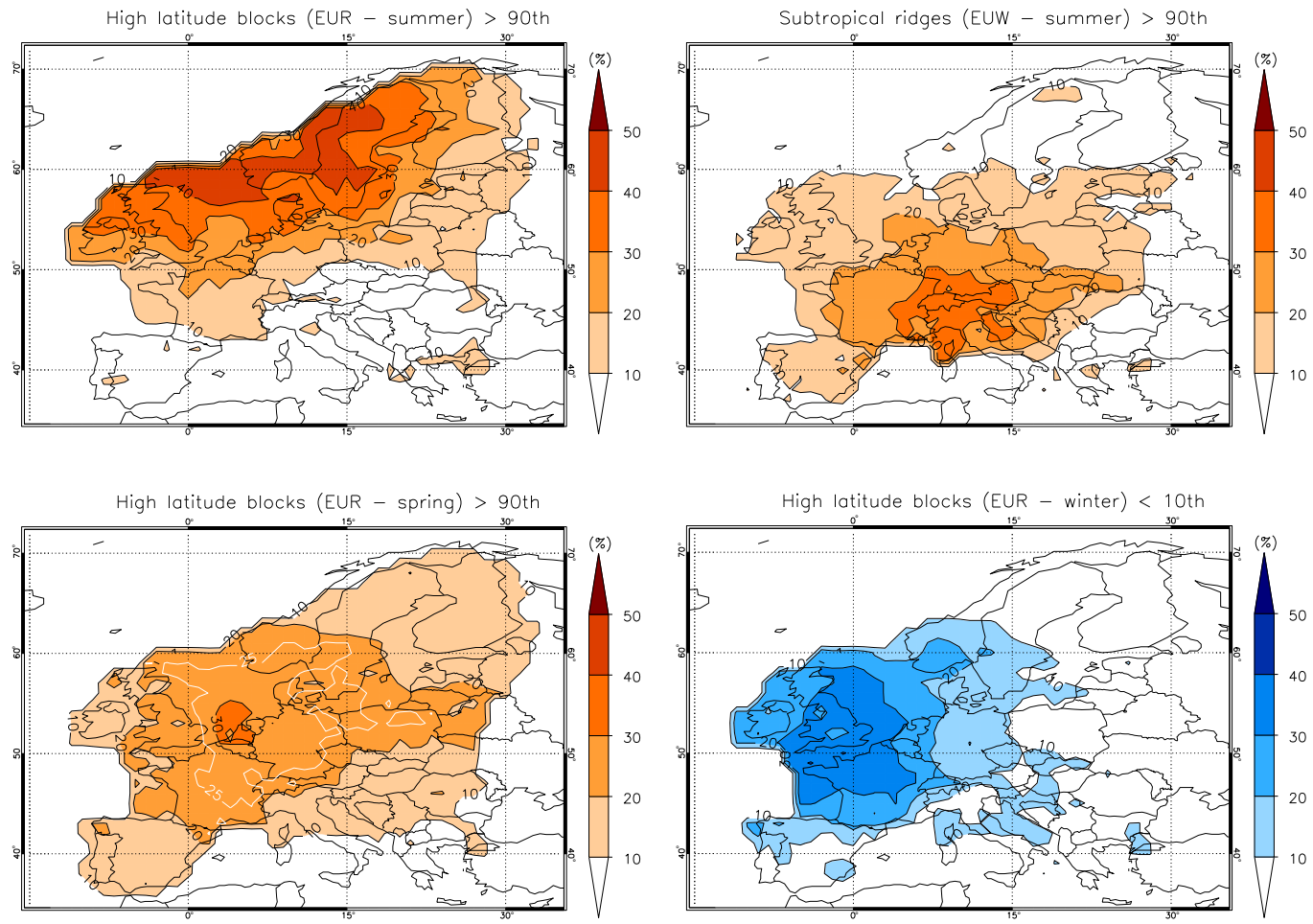

Figure 7. Percentage of EUR blocking days in summer (upper left) and spring (bottom left) as well as of days with ridges over the west of the EUR sector in summer $\left(0-15^{\circ} \mathrm{E}\right.$, upper right) for which $\mathrm{MDA} 8 \mathrm{O}_{3}$ is above the local 90th percentile of its seasonal distribution. The lower right panel also shows the percentage of EUR blocking days with MDA8 $\mathrm{O}_{3}$ below the 10th percentile of its seasonal distribution in winter.

EU" box, and to a lesser extent in the "East EU" box, with the presence of ridges in the European sector. These three cases are indicated by blue and red dashed lines in the lower panel of Fig. 5, all of them being significantly different from the climatology at the $0.1 \%$ level. Again, the maximum positive anomalies in those regions are observed when considering ridge centres located over narrow sectors covering the east Atlantic ( $15-0^{\circ}$ W; Fig. 8, lower left) and western Europe (0$15^{\circ} \mathrm{E}$; Fig. 8, lower right). The first situation is associated with large ozone anomalies well above $10 \mathrm{ppb}$ in Portugal and negative anomalies in Eastern Europe; overall, the largest positive/negative anomalies seen in the figure seem to be related to increases/decreases in daily maximum temperature over the west/east of the continent, but the impact of other meteorological fields may also play a role. The second situation yields average MDA8 $\mathrm{O}_{3}$ increases above $10 \mathrm{ppb}$ over a larger region, including northern Italy and the surrounding countries, also causing exceedances of the 90th percentile on more than $30 \%$ of the days for many of these locations (Fig. 7, upper right). This increase in ozone extremes is not as strong as that seen for northern Europe on days with EUR blocks during the same season (Fig. 7, upper left). Moreover, the importance of the persistence of ridges for the build-up of $\mathrm{O}_{3}$ is not as clear as in the case of blocks (not shown). How- ever, the impact on air quality exceedances is noteworthy. This occurs because the "Central/South EU" region is subject to higher surface $\mathrm{O}_{3}$ levels than other regions. In fact, this is the only region from those analysed here where the summer 90th percentile exceeds $60 \mathrm{ppb}$ (lower panel of Fig. 5) and it also includes the Po Basin, where average MDA8 $\mathrm{O}_{3}$ mixing ratios are $\sim 55 \mathrm{ppb}$ in this season. As a consequence, the occurrence of ridges within $0-15^{\circ} \mathrm{E}$ pushes the ozone levels high enough so that more than $40 \%$ of the days with this synoptic situation breach the $60 \mathrm{ppb}$ target over a large area including most of the northern half of Italy, the south-east of France, Switzerland and the south-west of Germany (Fig. 9). This failure to meet the MDA8 $\mathrm{O}_{3}$ target even occurs on more than $60 \%$ of the days over most of the Po Basin and above $80 \%$ of the days in a smaller region in the proximity of $\mathrm{Mi}-$ lan.

\section{Impact of high-latitude blocks and subtropical ridges on $\mathrm{MDA}_{3} \mathrm{O}_{3}$ during winter}

As introduced in Sect. 2 and also documented by previous analyses (Laurila, 1999), during winter predominantly westerly winds from the Atlantic advect background ozone into the European continent, which is a net sink region for ozone. 

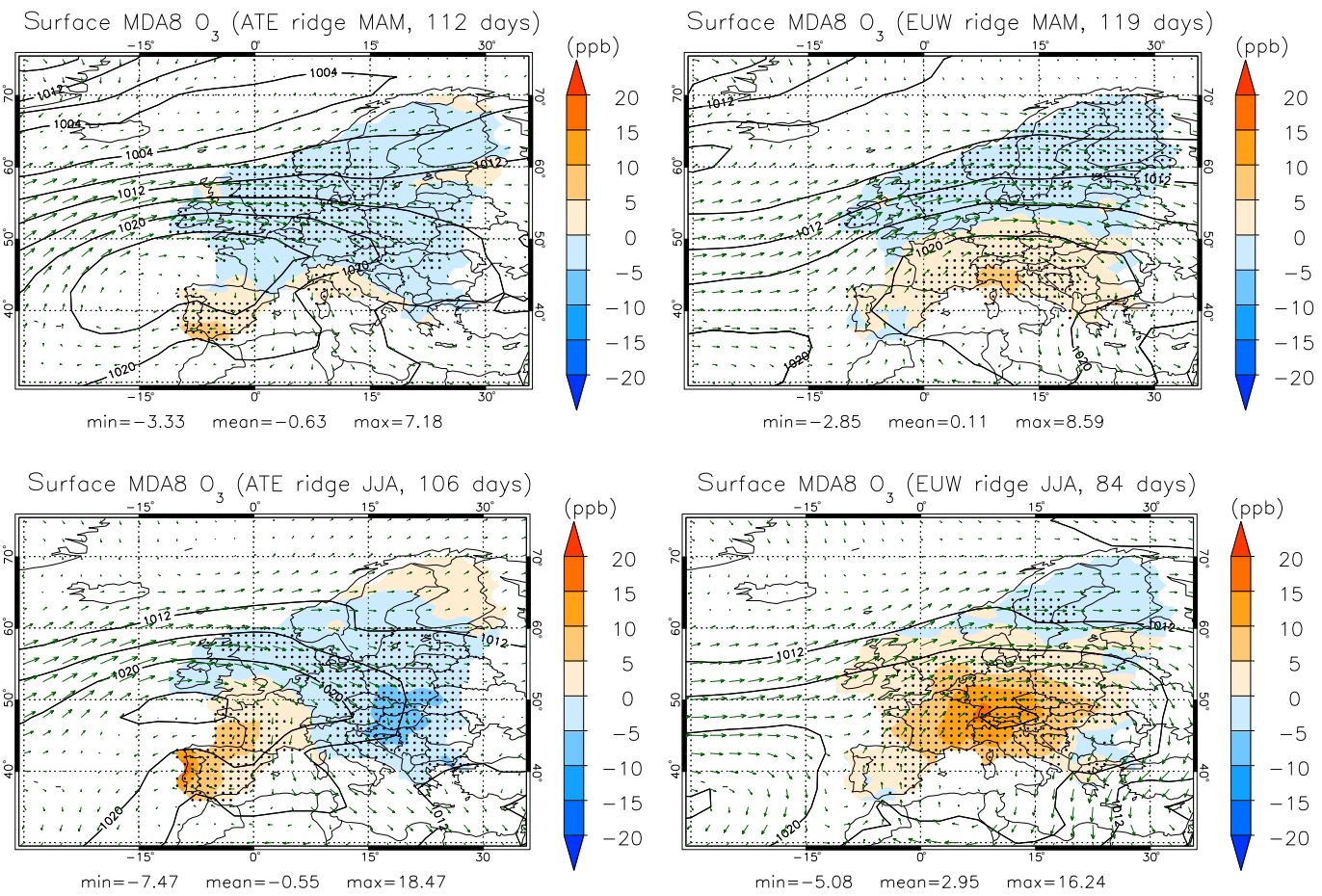

Figure 8. As Fig. 4 but for subtropical ridges with centres over the east Atlantic $\left(15-0^{\circ} \mathrm{W}\right.$, left $)$ and the west of the EUR sector $\left(0-15^{\circ}\right.$ E, right) in spring (top) and summer (bottom).

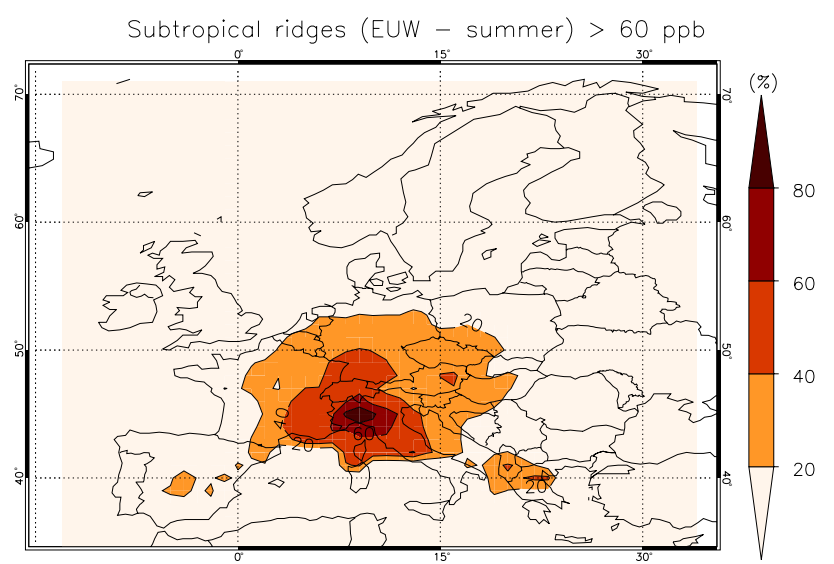

Figure 9. Percentage of summer days with ridge centres within the west flank of the EUR sector $\left(0-15^{\circ} \mathrm{E}\right)$ for which the $60 \mathrm{ppb}$ MDA8 $\mathrm{O}_{3}$ target is breached. Note the similar geographic location of the region with exceedances on more than $40 \%$ of the days in this figure and that where the local 90th percentile is surpassed on more than $30 \%$ of the days under this synoptic situation (Fig. 7, upper right).

As a consequence, the impact of blocking on surface ozone is expected to be the opposite of that found in summer. Blocking situations divert the western zonal flow and are associated with stagnation, which impedes the arrival of ozone-rich background air masses from the Atlantic and favours the accumulation of pollutants in the boundary layer, reducing sur- face ozone levels. This can be seen over the north-west of the continent in the composites of winter MDA8 $\mathrm{O}_{3}$ anomalies for blocking centres remaining in the ATL and EUR sectors (Fig. 10, upper and middle panels) and over central Europe for blocking centres in the RUS sector (Fig. 10, bottom panel). The anticyclone located above the British Isles under ATL blocking situations (Fig. 10, upper panel) diverts the typical westerly flow that is present in the climatology (Fig. 1, bottom panel), although only relatively small negative anomalies of up to around $-5 \mathrm{ppb}$ are found in that region as well as in other countries of western Europe. The impact of EUR blocking over the UK, northern France and the Benelux is stronger, yielding MDA8 $\mathrm{O}_{3}$ negative anomalies of up to around $-10 \mathrm{ppb}$ (Fig. 10, middle panel). This occurs because under the influence of ATL blocking, northwestern Europe is exposed to air masses which recirculate over the Atlantic, whilst the position of the EUR blocking high better shields the arrival of maritime air masses and it is concomitant with weak winds (on average from 2 to $4 \mathrm{~m} \mathrm{~s}^{-1}$ lower than the climatology at $850 \mathrm{hPa}$ ) which transport ozone-depleted continental air masses to those regions. We have also found that with the latter synoptic situation there are large areas of the continent where cloud cover decreases up to $\sim 25 \%$, enhancing the loss of longwave radiation at the surface and decreasing daily mean temperatures up to around $7^{\circ} \mathrm{C}$. Such conditions are expected to result in low mixing heights and temperature inversions, thus favour- 

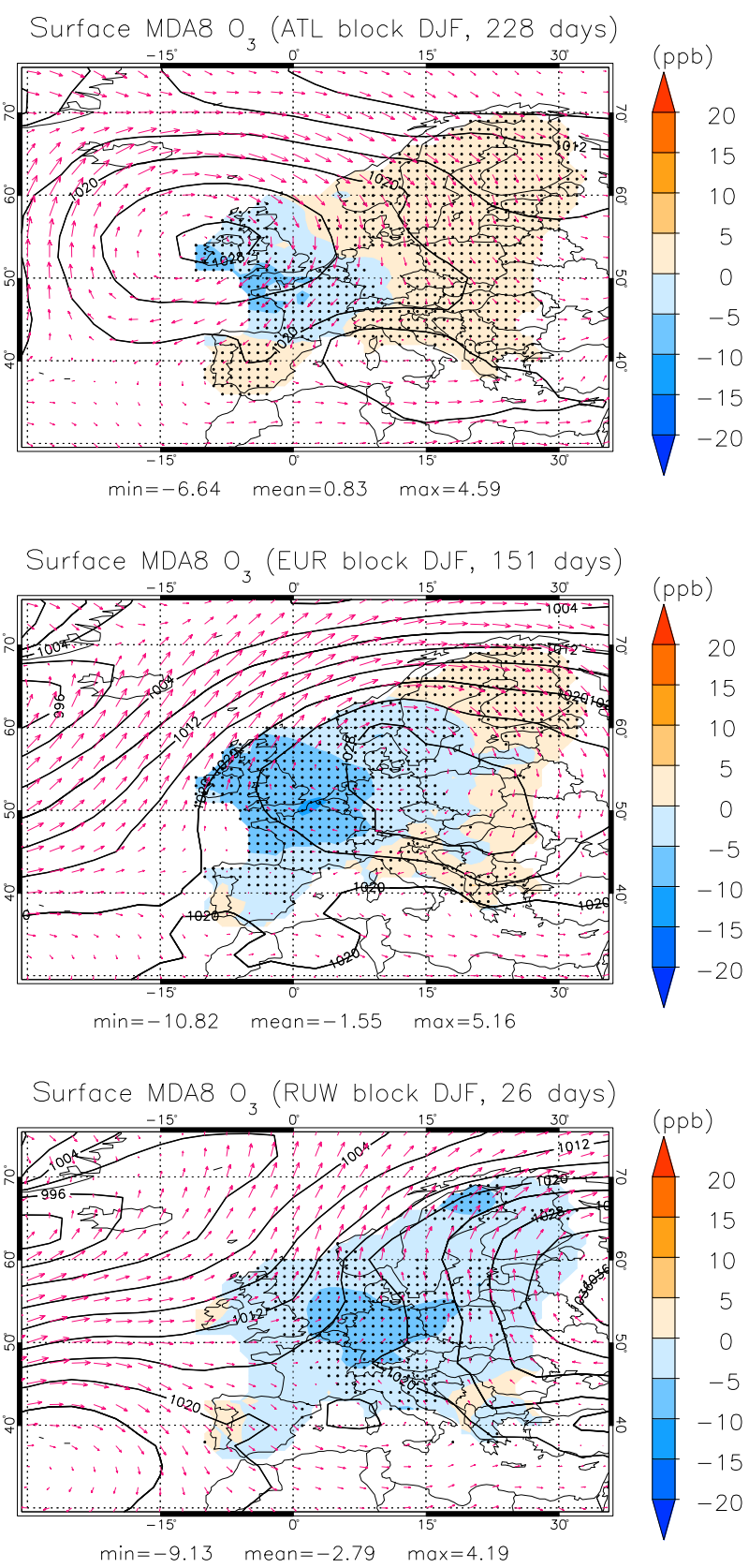

Figure 10. As Fig. 4 but for blocking centres remaining in the Atlantic $\left(30-0^{\circ} \mathrm{W}\right.$, top) and European $\left(0-30^{\circ} \mathrm{E}\right.$, middle) sectors as well as in the west flank of the Russian sector $\left(30-45^{\circ} \mathrm{E}\right.$, bottom) in winter.

ing the accumulation of primary pollutants close to the surface and the titration of $\mathrm{O}_{3}$ by NO.

The PDFs of MDA8 $\mathrm{O}_{3}$ in winter (Fig. 11) also highlight the increase in the number of low ozone events within the "UK/North Fr" and "Central/North EU" boxes under EUR blocking (red solid lines) and, to a lesser extent, in the "UK/North Fr" box when blocking centres are located over the ATL sector (blue solid line). The three distributions dif- fer significantly from the climatology at the $0.1 \%$ level (twosample $\mathrm{K}-\mathrm{S}$ test). In particular, the percentage of the ozone occurrences below $20 \mathrm{ppb}(10 \mathrm{ppb})$ in "UK/North Fr" associated with ATL and EUR blocking is 24 and $24 \%$ (25 and $39 \%$ ), respectively. Similarly, there is a shift to the left of the MDA8 $\mathrm{O}_{3}$ PDF over the "Central/North EU" and "NE Scandinavia" boxes on days with blocking centres over the Russian sector (green lines, Fig. 11), this change being significant at the $0.1 \%$ level only for the latter region. This situation is mainly found with blocking centres over the west flank of that sector $\left(30-45^{\circ} \mathrm{E}\right)$, which divert the westerly flow and result in weak winds that transport continental air masses from the south to those regions (Fig. 10, bottom). The figure shows some areas such as the Iberian Peninsula and the British Isles receiving westerly flow from the Atlantic, but the negative ozone anomalies are relatively small in those regions, while the strong negative ozone anomalies of 5-9 ppb found in a large area around Germany and in a smaller region in the north of Scandinavia have different origins. The first region is subject to weak MSLP gradients and consequently low wind speeds (on average of $2-4 \mathrm{~m} \mathrm{~s}^{-1}$ lower than the climatology at $850 \mathrm{hPa}$ ), which should inhibit the ventilation of the boundary layer and favour the loss of ozone by titration at this time of the year. In the second region wind speed increases us much as $3-5 \mathrm{~m} \mathrm{~s}^{-1}$, but is expected to bring ozonedepleted continental air masses from the south (note that at this time of the year average surface $\mathrm{O}_{3}$ levels in northern Scandinavia are higher than in the south, as seen from the lower panel of Fig. 1).

The blocking-related decreases in surface $\mathrm{O}_{3}$ over northern Europe concur with an overall reduction of the winter total ozone column (TOC) as reported by Barriopedro et al. (2010a). Their results obey to different mechanisms, as they found that blocking substantially increases the frequency of extremely low TOC values and ozone mini-holes mainly due to the combined effect of horizontal transport of ozone-poor air and vertical motions in the lower stratosphere.

While the overall response to winter blocking is characterized by $\mathrm{O}_{3}$ decreases, it is worthwhile to mention several regions that actually experience rising levels of MDA8 $\mathrm{O}_{3}$. For example, ATL blocking is associated with a shift to the right in the PDF of MDA8 $\mathrm{O}_{3}$, resulting in statistically significant changes with respect to the climatology at the $0.1 \%$ level for the two eastern boxes ("NE Scandinavia" and "East EU", Fig. 11). This is particularly the case for the "East EU" box, as it is often under the influence of westerly flow which is expected to bring ozone-depleted continental air masses (Fig. 1, bottom panel) while it is more exposed to background air masses from the ocean under ATL blocking (Fig. 10, upper panel).

The PDFs in Fig. S6 show the responses of different regions to ATL, EUR and RUS ridges. Unlike in the warm seasons, during winter the effects of ridges in northern regions of Europe tend to be the opposite to those of blocks. As an example, Fig. 12 (left) illustrates the MDA8 $\mathrm{O}_{3}$ re- 


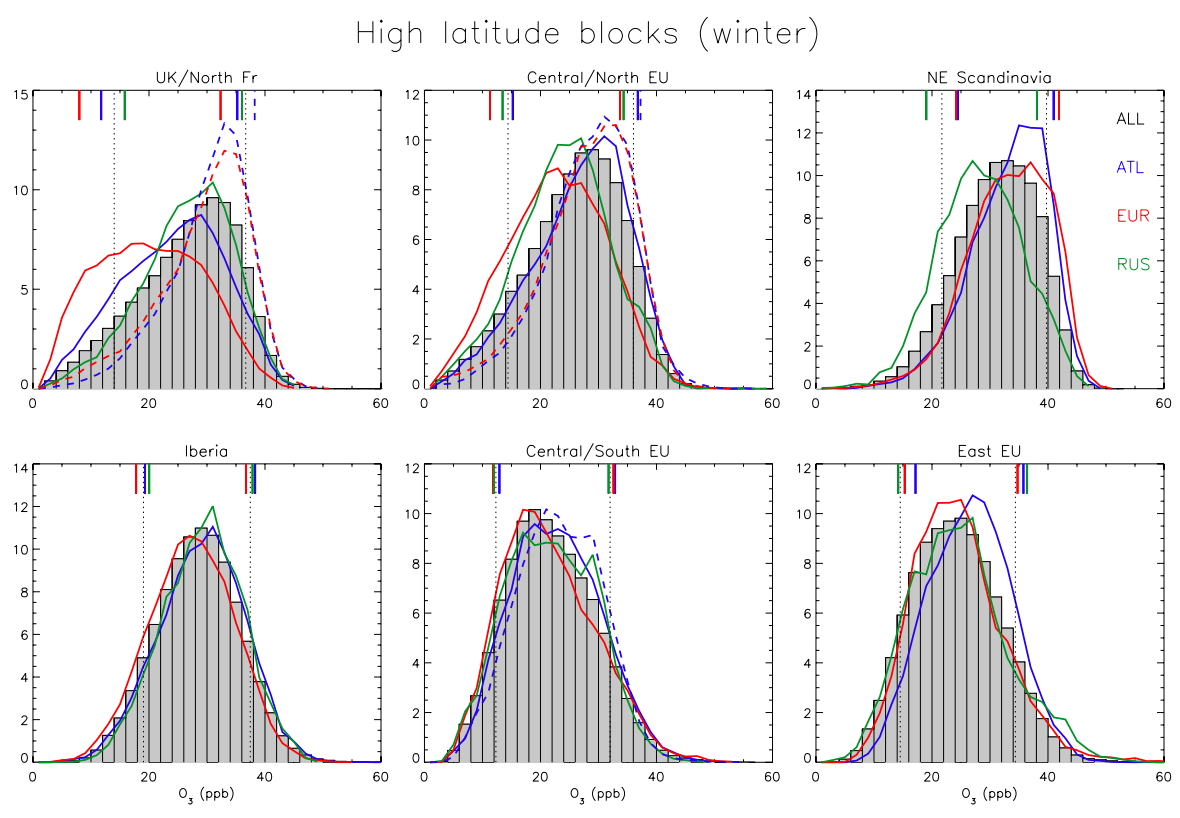

Figure 11. As Fig. 5 but for winter blocking. Note that blue and red dashed lines have been added to represent the frequency distributions of the data within the "UK/North Fr" and "Central/North EU" boxes when ridge centres are located over the ATL and EUR sectors, respectively. Data on days with ATL ridges are also shown for the "Central/South EU" region.

sponses to ATL ridges. Iberia is under the influence of the Azores high and the isobars are tightly packed over the UK and downwind regions. The stable weather conditions in Iberia result in moderate negative ozone anomalies, while the strong zonal flow in the north brings background air masses into the continent and ventilates the boundary layer, yielding ozone increases in excess of $5 \mathrm{ppb}$ over some areas of the British Isles and the Benelux. Anomalies of similar magnitude become more widespread, extending from the British Isles to the northern half of Germany when ridge centres are located in the east of the ATL sector $\left(15-0^{\circ}\right.$ W, Fig. 12, right). Similar features, with moderate ozone decreases in the south (not only "Iberia" but also the "Central/South EU" box) associated with weak MSLP gradients and horizontal wind speeds at lower levels, as well as ozone increases in the north ("UK/North Fr" and "Central/North EU" boxes), are patent when ridge centres are located over the EUR sector. The shift towards higher MDA8 $\mathrm{O}_{3}$ mixing ratios within the "UK/North Fr" and to a lesser extent in the "Central/North EU" boxes under the influence of subtropical ridges with centres over the ATL and EUR sectors can also be seen in Fig. 11 (blue and red dashed lines). The effect of ATL ridges can even be detected for the "Central/South EU" region (also indicated by a blue dashed line). The five distributions are statistically different from those of their respective climatologies at the $0.1 \%$ level. In particular, the PDFs become much narrower and are displaced to the right for the "UK/North Fr" box. From the visual inspection of the PDFs, the completely opposite impacts of ATL and EUR ridges (blue and red dashed lines, $\mathrm{O}_{3}$ increase) compared to those of ATL and
EUR blocks (blue and red solid lines, $\mathrm{O}_{3}$ decrease) are also evident over that area.

The different regional responses of near-surface ozone to blocks and ridges found here for winter are not observed in other seasons. This is in line with the results of Sousa et al. (2017) who found that while near-surface temperatures increase over different parts of Europe with the presence of both blocks and ridges in summer, they decrease/increase under the influence of blocks/ridges over large parts of the continent in winter. This opposite response also manifests in the exceedance of low and high ozone extremes (10th and 90th percentiles of the winter distribution, respectively). While more than $30 \%$ of the winter days with EUR blocking are associated with ozone levels below the 10th percentile over England and northern France (lower right panel of Fig. 7), over $20 \%$ of the days with ATL ridges are concurrent with exceedances of the 90th percentile in the proximity of the North Sea (Fig. S7).

\section{Role of blocks and ridges in the interannual variability of $\mathrm{O}_{3}$}

So far we have shown that summer $\mathrm{O}_{3}$ mixing ratios in northern Europe increase on days with blocking centres remaining over the EUR sector, while in other parts of the continent they are more sensitive to ridges within the east flank of the ATL sector $\left(15-0^{\circ} \mathrm{W}\right)$ and the west of the EUR sector $\left(0-15^{\circ} \mathrm{E}\right)$. Moreover, winter $\mathrm{O}_{3}$ in north-western Europe decreases on days with blocks in the ATL and EUR sectors and increases 

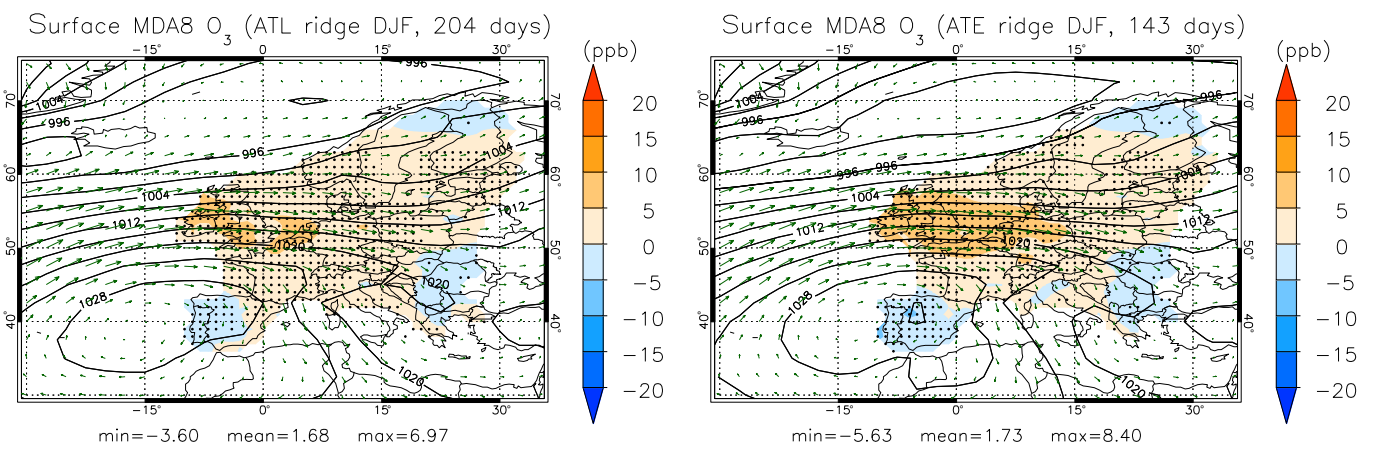

Figure 12. As Fig. 4 but for subtropical ridge centres in the Atlantic $\left(30-0^{\circ} \mathrm{W}\right.$, left) and east Atlantic $\left(15-0^{\circ} \mathrm{W}\right.$, right) in winter.

on days with ridges in the ATL sector. There remains the question of whether these synoptic situations can explain the interannual variability of $\mathrm{O}_{3}$.

We have examined this by trying to predict a number of seasonal ozone statistics as a function of the frequency of occurrence of blocks and ridges within each sector and season. After some sensitivity tests, we have found that the strongest responses are found for the number of exceedances of the local 90th percentiles of summer $\mathrm{O}_{3}$ and for the seasonal mean mixing ratios in the case of winter $\mathrm{O}_{3}$. The former (summer 90th $\mathrm{O}_{3}$ ) can be modelled by Eq. (1) as a multiple linear fit on the number of blocks in the EUR sector ( $\left.n_{\text {EUR_blocks }}\right)$, the number of ridges in the east of the ATL sector ( $\left.n_{\text {ATE_ridges }}\right)$ and the number of ridges in the west of the EUR sector $\left(n_{\text {EUW_ridges }}\right)$ during each summer. The latter (winter mean $\mathrm{O}_{3}$ ) has been fitted as a simpler linear combination of the number of blocks and ridges within the east of the ATL sector ( $n_{\text {ATE_blocks }}$ and $\left.n_{\text {ATE_ridges }}\right)$ during each winter, as seen from Eq. (2).

$$
\begin{aligned}
\text { summer 90th } \mathrm{O}_{3}= & a_{1}+b_{1} \cdot n_{\text {EUR_blocks }} \\
& +c_{1} \cdot n_{\text {ATE_ridges }}+d_{1} \cdot n_{\text {EUW_ridges }}+\varepsilon \\
\text { winter mean } \mathrm{O}_{3}= & a_{2}+b_{2} \cdot n_{\text {ATE_blocks }} \\
& +c_{2} \cdot n_{\text {ATE_ridges }}+\varepsilon .
\end{aligned}
$$

Here $a_{1}$ and $a_{2}$ are intercepts of both models; $b_{1}, c_{1}, d_{1}, b_{2}$ and $c_{2}$ are coefficients of the total number of blocks/ridges per season within a given sector; and $\varepsilon$ is the random error.

The total number of events considered during the 15 -year period are large enough - ranging from 84 cases of summer ridges in the west of Europe to 143 winter days with ridges in the east of the Atlantic - so that the interannual variability of these synoptic situations can be used to predict that of surface $\mathrm{O}_{3}$. Fifteen data points representing the seasonal values in each year have been fitted separately for every grid cell in both cases. The significance of the regression models has been tested by carrying out an analysis of variance ( $F$ test; see e.g. von Storch and Zwiers, 1999) at the $5 \%$ level.

The models have skill in reproducing the interannual variability of $\mathrm{O}_{3}$. The explained variance $\left(R^{2}\right)$ is above $40 \%$ over large parts of western Europe in summer (top panel of Fig. 13), whereas $R^{2}$ exceeds $60 \%$ in a more compact area spanning from the British Isles to western Germany during winter (bottom panel of Fig. 13). The larger extension of the area with $R^{2}$ values exceeding $40 \%$ in the case of summer is due to the fact that Eq. (1) considers three synoptic situations which tend to impact surface $\mathrm{O}_{3}$ over different regions of the continent. Actually, the linear fit is significant at the $5 \%$ level over three separate regions which correspond to the main centres of action of these patterns (southern Scandinavia, EUR blocks; western Iberia, ridges in the east of the ATL sector; western-central Europe, ridges in the west of the EUR sector). The power of the second model (Eq. 2) to predict the interannual variability of winter mean $\mathrm{O}_{3}$ over a more localised area of north-western Europe is not surprising either. During that season, blocks and ridges in the proximity of the ATL sector are respectively responsible for a considerable fraction of the days with the lowest and highest $\mathrm{O}_{3}$ concentrations around the same region, both of them contributing to deviations from the winter mean values; as a consequence, $R^{2}$ values are large and the linear model is significant at the $5 \%$ level over the whole area. Note that these models are relatively simple and that higher values of $R^{2}$ can be found, in particular, in the east of the continent if the frequencies of occurrence of blocks and ridges within more longitudinal sectors are included as predictors in Eqs. (1) and (2) (not shown). In addition, the reduced data sample (only 15 years) imposes a limit on the statistical significance of the results shown here.

Our results can be put in the context of previous work which has tried to assess the role of the atmospheric circulation in the interannual variability of surface $\mathrm{O}_{3}$. Pausata et al. (2012) found that the correlation coefficients $(R)$ between monthly ozone mixing ratios and the monthly NAOI exceed 0.50 only at some locations in northern and central Europe in winter, while all correlations get smaller in summer even if a modified NAOI is used. Leibensperger et al. (2008) reported that summertime mid-latitude cyclones are good predictors of ozone pollution days in the eastern US, with negative correlations exceeding -0.50 over most 

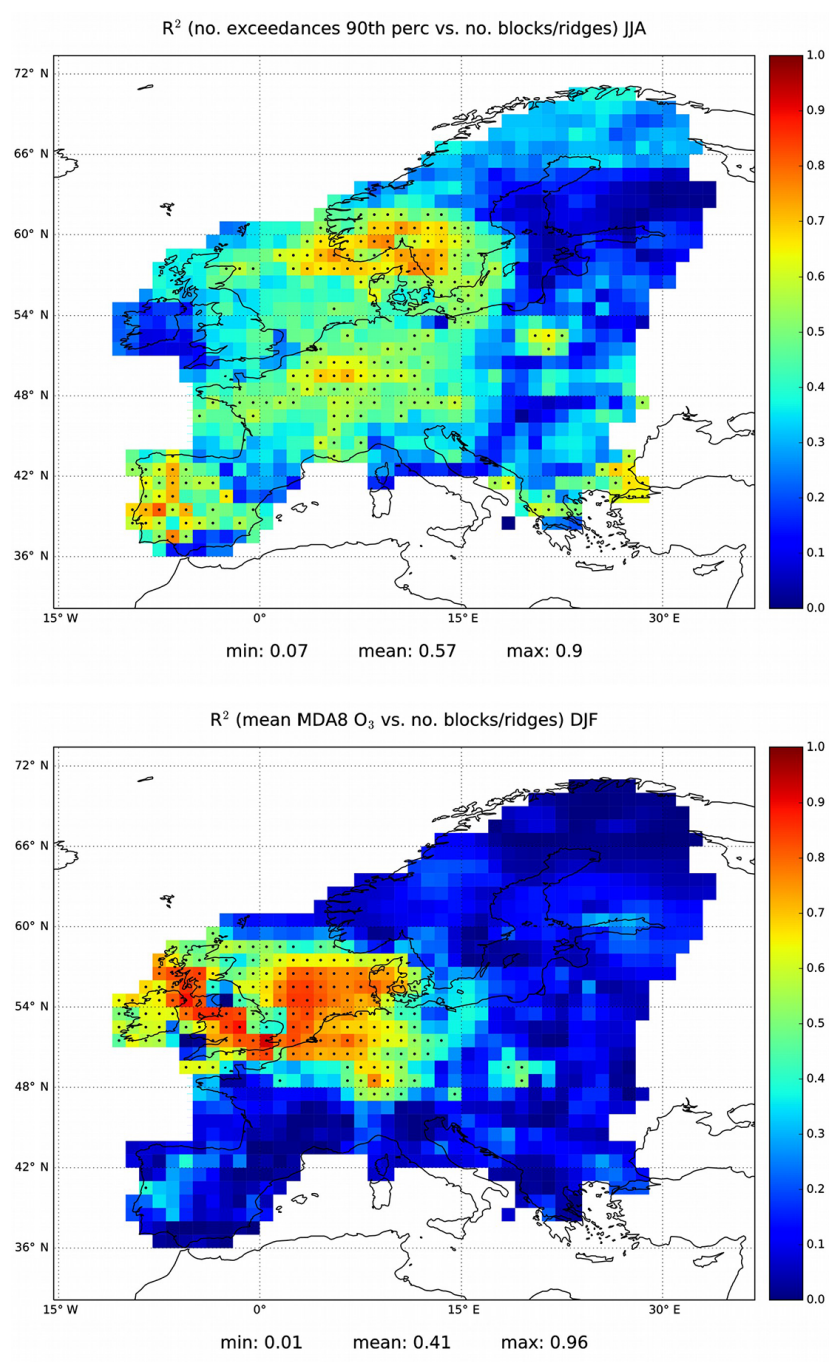

Figure 13. Coefficient of determination $\left(R^{2}\right)$ of two multiple linear models predicting the number of exceedances of the 90th $\mathrm{O}_{3}$ percentile in summer (top panel, Eq. 1) and the winter mean $\mathrm{O}_{3}$ mixing ratios (bottom panel, Eq. 2) over each grid cell as a function of the interannual variability of blocks and ridges. Stippling indicates the locations where the multiple linear fits are significant at the $5 \%$ level ( $F$ test).

areas. Barnes and Fiore (2013) showed that present day summertime variability of surface ozone depends strongly on the jet stream position over the north-eastern US and that this relationship holds under projected climate change scenarios in which surface ozone variability follows the poleward shift of the jet $\left(R^{2}=0.69\right)$. More recently, Shen et al. (2015) have constructed a multiple linear regression model of mean JJA MDA8 $\mathrm{O}_{3}$ in the eastern US on meteorological variables describing the polar jet frequency and the position of the Bermuda High west edge, finding $R^{2}$ values from 0.53 to 0.71 depending on the region. Our results should be interpreted with caution because of the smaller data sample (15 years of European $\mathrm{O}_{3}$ observations) compared to that of previous studies in the US (around 30 years of observations and longer for modelling studies), but they indicate that the frequency of occurrence of blocks and ridges can explain a considerable fraction of the total variance in the seasonal ozone levels over some regions of western Europe.

\section{Summary and discussion}

We have used a catalogue of high-latitude blocks and subtropical ridges occurring in three distinct $30^{\circ}$ longitudinal sectors (ATL, EUR, RUS) covering the Euro-Atlantic region, together with a 15-year gridded European surface $\mathrm{O}_{3}$ dataset, to examine the regional responses of MDA8 $\mathrm{O}_{3}$ to the occurrence, position and persistence of blocks and ridges. The maximum ozone anomalies often follow the longitudinal position of the block and ridge centres. As both synoptic patterns disrupt the atmospheric circulation over large areas far from their centres of action, they also exert a moderate influence on the surface ozone levels in distant regions.

We have found a strong impact of blocks on $\mathrm{O}_{3}$ during spring and summer. In particular, EUR blocking is associated with ozone increases over large areas of Europe in both seasons, with anomalies around 5-10 ppb within the $40-60^{\circ} \mathrm{N}$ latitudinal band in spring and further north $\left(50-70^{\circ} \mathrm{N}\right)$ in summer. In addition, over 20 and $30 \%$ of the days with blocks in the EUR sector are concurrent with exceedances of the 90th percentile of the ozone distribution in those regions during spring and summer, respectively. Blocks within the ATL sector also yield moderate ozone increases over the UK in summer.

The impact of subtropical ridges on surface ozone during the warm seasons is significant over the centre and south of the continent, in particular during summer. Nonetheless, this effect is more sensitive to their specific location than in the case of blocks. Ridge centres located in the east Atlantic $\left(15-0^{\circ} \mathrm{W}\right)$ are associated with positive ozone anomalies well above $10 \mathrm{ppb}$ in Portugal during summer. More importantly, there is a large area including northern Italy and the surrounding countries where summer ozone anomalies exceed $10 \mathrm{ppb}$, often yielding MDA8 $\mathrm{O}_{3}$ mixing ratios above the $60 \mathrm{ppb}$ AQ target, when ridge centres are located in the west flank of the EUR sector $\left(0-15^{\circ} \mathrm{E}\right)$. It is worthwhile to indicate that the 15-year gridded ozone dataset used here does not include data in southern Italy. Other datasets of shorter duration but improved coverage over that region, such as the 10year gridded ozone fields produced by Schnell et al. (2014) or time series at selected sites, could be helpful to investigate the effect of ridges in that region. In addition, the joint examination of synoptic and mesoscale weather patterns is needed to better understand the localised impact of circulation on surface ozone in the Mediterranean.

It is well known that anticyclonic conditions, which occur both with high-latitude blocking episodes and under the influence of subtropical ridges, trap pollutants close to the 
surface in winter, yielding ozone decreases through the enhanced effect of titration and dry deposition. However, this study has revealed that blocks and ridges produce very different responses in surface ozone over the north-west of Europe during this season. The anticyclonic circulation associated with ATL blocking results in moderate ozone decreases over the UK, whereas the response to EUR blocking is stronger (with negative anomalies between -5 and $-10 \mathrm{ppb}$ ) over the UK, northern France and the Benelux. With the latter synoptic situation, the air masses are recirculating around the European continent, which acts as a sink for ozone during this season. Conversely, ATL and EUR ridges yield positive winter ozone anomalies in northern Europe, with values exceeding $5 \mathrm{ppb}$ over the British Isles, the Benelux and some parts of Germany. Whilst moderate ozone decreases are found in some southern areas of the continent, these synoptic situations, in particular ATL ridges, are associated with strong MSLP gradients and enhanced zonal flow around $50-60^{\circ} \mathrm{N}$, favouring the arrival of background air masses from the Atlantic and the ventilation of the boundary layer. Moreover, while $30 \%$ of the winter days with EUR blocks record ozone levels lower than the 10th percentile in England and northern France, above $20 \%$ of the days with ATL ridges coincide with exceedances of the 90th percentile around the British Isles and the Benelux. Thus, during winter, blocks and ridges lead to opposite effects in both surface ozone mean anomalies and extremes, particularly in northern countries. These findings might not look relevant from the AQ perspective as threshold values for this pollutant are rarely exceeded at most mid-latitude locations in winter. However, these results have potential implications for primary pollutants and particulate matter (PM), whose response is expected to be the opposite to that of ozone. We anticipate that blocking will result in elevated $\mathrm{NO}_{2}$ and $\mathrm{PM}$ levels in north-western Europe during winter, and that the changes in the circulation at those latitudes introduced by the influence of subtropical ridges will ventilate the west of the continent. The impact of these synoptic patterns on winter $\mathrm{PM}_{10}$ (particulate matter with aerodynamic diameter up to $10 \mu \mathrm{m}$ ) in Europe will be the subject of another publication.

Finally, we have built multiple linear models of some seasonal ozone statistics on the frequency of occurrence of blocks and ridges, proving that these have some skill in controlling the interannual variability of summer and winter ozone over western Europe. The explained variance is considerably larger than that captured by the monthly NAOI for European ozone (e.g. Pausata et al., 2012).

\section{Implications and future directions}

A warming climate is expected to increase peak levels of $\mathrm{O}_{3}$ in polluted regions, an impact that has been referred to as a climate change penalty on AQ. The response of ozone to temperature changes as modelled by both CCMs and CTMs re- lies on the parameterisation of a number of processes whose temperature dependence is uncertain (e.g. biogenic emissions, which also depend on other environmental factors) or difficult to quantify in practice (e.g. extra evaporation of anthropogenic NMVOCs under high temperatures). Moreover, in regions with a significant contribution of biogenic emissions, ozone-temperature relationships are strongly affected by major uncertainties in the chemistry of isoprene within the models, in particular the isoprene nitrate yields and the fate of these nitrates. Further details on these and other issues can be found e.g. in Vautard et al. (2005), Jacob and Winner (2009), Fiore et al. (2012), Fu et al. (2015) and Zhang and Wang (2016). In addition, it is important to quantify the contribution of both thermodynamic (temperature and specific humidity) and dynamic (circulation) effects to future climate changes (e.g. Shepherd, 2014; Horton et al., 2015). Taking all this into account, future air pollution episodes cannot be modelled as all else being equal except for a uniform temperature shift. As a consequence, the Fifth Assessment Report of the Intergovernmental Panel on Climate Change (IPCC) indicates that projecting AQ empirically from a mean surface warming using observed correlations of air pollutants with temperature may be problematic, while establishing relationships with synoptic conditions may be more robust (Kirtman et al., 2013).

Following the IPCC's recommendations, the results from this work provide observational constraints for the processoriented evaluation of modelled $\mathrm{O}_{3}$ to changes in the occurrence and position of two types of synoptic patterns of great relevance for the weather and climate at the mid-latitudes. We have (i) quantified to what extent these patterns impact the day-to-day variability in the ozone concentrations and (ii) proved that their frequency of occurrence can explain a considerable fraction of the interannual variability of $\mathrm{O}_{3}$ over some areas of western Europe. Therefore, these patterns may serve as dynamical predictors of future ozone variability over this region and can be taken into account when projecting the effects of climate change on this pollutant.

It should be borne in mind that a number of studies have shown that climate models often underestimate blocking activity in different regions of the Northern Hemisphere (e.g. Scaife et al., 2010; Barriopedro et al., 2010c; Barnes et al., 2012; Anstey et al., 2013; Dunn-Sigouin et al., 2013), with potentially different origins of the model biases depending on the region and season (e.g. Vial and Osborn, 2012; Zappa et al., 2014). The ability of some models to simulate blocking is improving, but future trends in blocking are still uncertain (Christensen et al., 2013). Note also that the frequency of blocking may vary across different blocking detection methods and among different reanalysis datasets (e.g. Barnes et al., 2014). To the authors' knowledge, there have been no attempts to evaluate ridge activity over the North Atlantic European region in climate models.

Despite the mentioned uncertainties, our results provide quantitative assessments of the response of surface ozone 
to circulation changes which can be exploited to evaluate CTMs, as these are driven by meteorological reanalyses like the one used in this work. In this context, the problem with the underestimation of blocking activity in climate models can also be overcome to some extent by the use of ensembles of historical CCM simulations, which would provide a high enough number of blocking and ridge events whose impacts on surface ozone could be compared with our observational assessments. The analyses conducted here for European ozone can also be extended to other mid-latitude regions and other pollutants like PM in a relatively easy manner. Future efforts in this direction, in combination with improvements in the representation of blocking and ridge activity in climate models, will help understand the contribution of dynamic effects to near-term projections of $\mathrm{AQ}$.

Data availability. NCEP Reanalysis data are provided by the NOAA/OAR/ESRL PSD, Boulder, Colorado, USA, from their web site at http://www.esrl.noaa.gov/psd/. The ozone dataset and the catalogue of blocks and ridges can be obtained from the authors of this paper.

\section{The Supplement related to this article is available online at doi:10.5194/acp-17-3111-2017-supplement.}

Competing interests. The authors declare that they have no conflict of interest.

Acknowledgements. Carlos Ordóñez acknowledges funding from the Ramón y Cajal Programme of the Spanish Ministerio de Economía y Competitividad under grant RYC-2014-15036.

Edited by: S. Galmarini

Reviewed by: two anonymous referees

\section{References}

Anstey, J. A., Davini, P., Gray, L. J., Woollings, T. J., Butchart, N., Cagnazzo, C., Christiansen, B., Hardiman, S. C., Osprey, S. M., and Yang, S.: Multi-model analysis of Northern Hemisphere winter blocking: Model biases and the role of resolution, J. Geophys. Res.-Atmos., 118, 3956-3971, doi:10.1002/jgrd.50231, 2013.

Ashmore, M. R.: Assessing the future global impacts of ozone on vegetation, Plant Cell Environ., 28, 949-964, 2005.

Barnes, E. A. and Fiore, A. M.: Surface ozone variability and the jet position: Implications for projecting future air quality, Geophys. Res. Lett., 40, 2839-2844, doi:10.1002/grl.50411, 2013.

Barnes, E., Slingo, J., and Woollings, T.: A methodology for the comparison of blocking climatologies across indices, models and climate scenarios, Clim. Dynam., 38, 2467-2481, 2012.

Barnes, E. A., Dunn-Sigouin, E., Masato, G., and Woollings, T.: Exploring recent trends in Northern Hemisphere blocking,
Geophys. Res. Lett., 41, 638-644, doi:10.1002/2013GL058745, 2014.

Barriopedro, D., García-Herrera, R., Lupo, A. R., and Hernández, E.: A Climatology of Northern Hemisphere Blocking, J. Climate, 19, 1042-1063, 2006.

Barriopedro, D., Antón, M., and García, J. A.: Atmospheric blocking signatures in total ozone and ozone mini-holes, J. Climate, 23, 3967-3983, doi:10.1175/2010JCLI3508.1, 2010a.

Barriopedro, D., García-Herrera, R., and Trigo, R. M.: Application of blocking diagnosis methods to General Circulation Models, Part I: a novel detection scheme, Clim. Dynam., 35, 1373-1391, 2010b.

Barriopedro, D., García-Herrera, R., González-Rouco, J. F., and Trigo, R. M.: Application of blocking diagnosis methods to General Circulation Models, Part II: model simulations, Clim. Dynam., 35, 1393-1409, doi:10.1007/s00382-010-0766-6, 2010c.

Bloomfield, P. J., Royle, J. A., Steinberg, L. J., and Yang, Q.: Accounting for meteorological effects in measuring urban ozone levels and trends, Atmos. Environ., 30, 3067-3077, 1996.

Brunekreef, B. and Holgate, S. T.: Air pollution and health, The Lancet, 360, 1233-1242, 2002.

Buehler, T., Raible, C. C., and Stocker, T. F.: The relationship of winter season North Atlantic blocking frequencies to extreme cold or dry spells in the ERA-40, Tellus A, 63, 212-222, 2011.

Camalier, L., Cox, W., and Dolwick, P.: The effects of meteorology on ozone in urban areas and their use in assessing ozone trends, Atmos. Environ., 41, 7127-7137, 2007.

Carvalho, A., Monteiro, A., Ribeiro, I., Tchepel, O., Miranda, A. I., Borrego, C., Saavedra, S., Souto, J. A., and Casares, J. J.: High ozone levels in the northeast of Portugal: Analysis and characterization, Atmos. Environ., 44, 1020-1031, 2010.

Cattiaux, J., Vautard, R., Cassou, C., Yiou, P., Masson-Delmotte, V., and Codron, F.: Winter 2010 in Europe: A cold extreme in a warming climate, Geophys. Res. Lett., 37, L20704, doi:10.1029/2010GL044613, 2010.

Christensen, J. H., Krishna Kumar, K., Aldrian, E., An, S.-I., Cavalcanti, I. F. A., de Castro, M., Dong, W., Goswami, P., Hall, A., Kanyanga, J. K., Kitoh, A., Kossin, J., Lau, N.-C., Renwick, J., Stephenson, D. B., Xie, S.-P., and Zhou, T.: Climate Phenomena and their Relevance for Future Regional Climate Change, in: Climate Change 2013: The Physical Science Basis, Contribution of Working Group I to the Fifth Assessment Report of the Intergovernmental Panel on Climate Change, edited by: Stocker, T. F., Qin, D., Plattner, G.-K., Tignor, M., Allen, S. K., Boschung, J., Nauels, A., Xia, Y., Bex, V., and Midgley, P. M., Cambridge University Press, Cambridge, UK, New York, NY, USA, 2013.

Creilson, J. K., Fishman, J., and Wozniak, A. E.: Intercontinental transport of tropospheric ozone: a study of its seasonal variability across the North Atlantic utilizing tropospheric ozone residuals and its relationship to the North Atlantic Oscillation, Atmos. Chem. Phys., 3, 2053-2066, doi:10.5194/acp-3-2053-2003, 2003.

Cros, B., Durand, P., Cachier, H., Drobinski, Ph., Fréjafon, E., Kottmeier, C., Perros, P. E., Peuch, V.-H., Ponche, J.-L., Robin, D., Saïd, F., Toupance, G., and Wortham, H.: The ESCOMPTE program: an overview, Atmos. Res., 69, 241-279, 2004.

Demuzere, M., Trigo, R. M., Vila-Guerau de Arellano, J., and van Lipzig, N. P. M.: The impact of weather and atmospheric circulation on $\mathrm{O}_{3}$ and $\mathrm{PM}_{1} 0$ levels at a rural mid-latitude site, At- 
mos. Chem. Phys., 9, 2695-2714, doi:10.5194/acp-9-2695-2009, 2009.

Demuzere, M., Kassomenos, P., and Philipp, A.: The COST733 circulation type classification software: an example for surface ozone concentrations in Central Europe, Theor. Appl. Climatol., 105, 143-166, doi:10.1007/s00704-010-0378-4, 2011.

Doche, C., Dufour, G., Foret, G., Eremenko, M., Cuesta, J., Beekmann, M., and Kalabokas, P.: Summertime tropospheric-ozone variability over the Mediterranean basin observed with IASI, Atmos. Chem. Phys., 14, 10589-10600, doi:10.5194/acp-1410589-2014, 2014

Drobinski, P., Saïd, F., Ancellet, G., Arteta, J., Augustin, P., Bastin, S., Brut, A., Caccia, J. L., Campistron, B., Cautenet, S., Colette, A., Coll, I., Corsmeier, U., Cros, B., Dabas, A., Delbarre, H., Dufour, A., Durand, P., Guénard, V., Hasel, M., Kalthoff, N., Kottmeier, C., Lasry, F., Lemonsu, A., Lohou, F., Masson, V., Menut, L., Moppert, C., Peuch, V. H., Puygrenier, V., Reitebuch, O., and Vautard, R.: Regional transport and dilution during highpollution episodes in southern France: Summary of findings from the Field Experiment to Constraint Models of Atmospheric Pollution and Emissions Transport (ESCOMPTE), J. Geophys. Res., 112, D13105, doi:10.1029/2006JD007494, 2007.

Dunn-Sigouin, E., Son, S.-W., and Lin., H.: Evaluation of Northern Hemisphere Blocking Climatology in the Global Environment Multiscale Model, Mon. Weather Rev., 141, 707-727, doi:10.1175/MWR-D-12-00134.1, 2013.

European Environment Agency (EEA): Air quality in Europe 2015 report, EEA Report No 5/2015, Luxembourg, 57 pp., 2015.

Fiore, A. M., Naik, V., Spracklen, D. V., Steiner, A., Unger, N., Prather, M., Bergmann, D., Cameron-Smith, P. J., Cionni, I., Collins, W. J., Dalsøren, S., Eyring, V., Folberth, G. A., Ginoux, P., Horowitz, L. W., Josse, B., Lamarque, J.-F., MacKenzie, I. A., Nagashima, T., O’Connor, F. M., Righi, M., Rumbold, S. T., Shindell, D. T., Skeie, R. B., Sudo, K., Szopa, S., Takemurat, T., and Zengu, G.: Global air quality and climate, Chem. Soc. Rev., 41, 6663-6683, doi:10.1039/C2CS35095E, 2012.

Fiore, A. M., Naik, V., and Leibensperger, E. M.: Air Quality and Climate Connections, J. Air Waste Manag. Assoc., 65, 645-685, 2015.

Flocas, H., Kelessis, A., Helmis, C., Petrakakis, M., Zoumakis, M., and Pappas, K.: Synoptic and local scale atmospheric circulation associated with air pollution episodes in an urban Mediterranean area, Theor. Appl. Climatol., 95, 265-277, 2009.

Fraedrich, K., Bantzer, C., and Burkhardt, U.: Winter climate anomalies in Europe and their associated circulation at $500 \mathrm{hPa}$, Clim. Dynam., 8, 161-175, 1993.

Fu, T.-M., Zheng, Y., Paulot, F., Mao, J., and Yantosca, R. M.: Positive but variable sensitivity of August surface ozone to largescale warming in the southeast United States, Nat. Clim. Change, 5, 454-458, doi:10.1038/nclimate2567, 2015.

Gangoiti, G., Millán, M. M., Salvador, R., and Mantilla, E.: Longrange transport and re-circulation of pollutants in the western Mediterranean during the project Regional Cycles of Air Pollution in the West-Central Mediterranean Area, Atmos. Environ., 35, 6267-6276, 2001.

García-Herrera, R., Díaz, J., Trigo, R. M., Luterbacher, J., and Fischer, E. M.: A Review of the European Summer Heat Wave of 2003, Crit. Rev. Env. Sci. Tec., 40, 267-306, 2010.
Horton, D. E., Johnson, N. C., Singh, D., Swain, D. L., Rajaratnam, B., and Diffenbaugh, N. S.: Contribution of changes in atmospheric circulation patterns to extreme temperature trends, Nature, 522, 465-469, doi:10.1038/nature14550, 2015.

Hurrell, J. W.: Decadal trends in the North Atlantic Oscillation: Regional temperatures and precipitation, Science, 269, 676-679, 1995.

Jacob, D. J. and Winner, D. A.: Effect of climate change on air quality, Atmos. Environ., 43, 51-63, 2009.

Jones, P. D., Jonsson, T., and Wheeler, D.: Extension to the North Atlantic Oscillation using early instrumental pressure observations from Gibraltar and South-West Iceland, Int. J. Climatol., 17, 1433-1450, 1997.

Kalabokas, P. D., Cammas, J.-P., Thouret, V., Volz-Thomas, A., Boulanger, D., and Repapis, C. C.: Examination of the atmospheric conditions associated with high and low summer ozone levels in the lower troposphere over the eastern Mediterranean, Atmos. Chem. Phys., 13, 10339-10352, doi:10.5194/acp-1310339-2013, 2013.

Kalnay, E., Kanamitsu, M., Kistler, R., Collins, W., Deaven, D., Gandin, L., Iredell, M., Saha, S., White, G., Woollen, J., Zhu, Y., Chelliah, M., Ebisuzaki, W., Higgins, W., Janowiak, J., Mo, K. C., Ropelewski, C., Wang, J., Leetmaa, A., Reynolds, R., Jenne, R., and Joseph, D.: The NCEP/NCAR 40-Year Reanalysis Project, B. Am. Meteorol. Soc., 77, 437-471, 1996.

Katsafados, P., Papadopoulos, A., Varlas, G., Papadopoulou, E., and Mavromatidis, E.: Seasonal predictability of the 2010 Russian heat wave, Nat. Hazards Earth Syst. Sci., 14, 1531-1542, doi:10.5194/nhess-14-1531-2014, 2014.

Kirtman, B., Power, S. B., Adedoyin, J. A., Boer, G. J., Bojariu, R., Camilloni, I., Doblas-Reyes, F. J., Fiore, A. M., Kimoto, M., Meehl, G. A., Prather, M., Sarr, A., Schär, C., Sutton, R., van Oldenborgh, G. J., Vecchi G., and Wang, H. J.: Near-term Climate Change: Projections and Predictability, in: Climate Change 2013: The Physical Science Basis, Contribution of Working Group I to the Fifth Assessment Report of the Intergovernmental Panel on Climate Change, edited by: Stocker, T. F., Qin, D., Plattner, G.-K., Tignor, M., Allen, S. K., Boschung, J., Nauels, A., Xia, Y., Bex, V., and Midgley, P. M., Cambridge University Press, Cambridge, UK, New York, NY, USA, 2013.

Laurila, T.: Observational study of transport and photochemical formation of ozone over northern Europe, J. Geophys. Res., 104, 26235-26243, 1999.

Leibensperger, E. M., Mickley, L. J., and Jacob, D. J.: Sensitivity of US air quality to mid-latitude cyclone frequency and implications of 1980-2006 climate change, Atmos. Chem. Phys., 8, 7075-7086, doi:10.5194/acp-8-7075-2008, 2008.

Liu, L., Flatøy, F., Ordóñez, C., Braathen, G. O., Hak, C., Junkermann, W., Andreani-Aksoyoglu, S., Mellqvist, J., Galle, B., Prévôt, A. S. H., and Isaksen, I. S. A.: Photochemical modelling in the Po basin with focus on formaldehyde and ozone, Atmos. Chem. Phys., 7, 121-137, doi:10.5194/acp-7-121-2007, 2007.

Martilli, A., Neftel, A., Favaro, G., Kirchner, F., Sillman, S. and Clappier, A.: Simulation of the ozone formation in the northern part of the Po Valley, J. Geophys. Res., 107, 8195, doi:10.1029/2001JD000534, 2002.

Masato, G., Hoskins, B. J., and Woollings, T. J.: Wave-breaking characteristics of midlatitude blocking, Q. J. Roy. Meteor. Soc., 138, 1285-1296, doi:10.1002/qj.990, 2012. 
Matsueda, M.: Predictability of Euro-Russian blocking in summer of 2010, Geophys. Res. Lett., 38, L06801, doi:10.1029/2010GL046557, 2011.

Millán, M. M., Mantilla, E., Salvador, R., Carratalá, A., Sanz, M. J., Alonso, L., Gangoiti, G., and Navazo, M.: Ozone Cycles in the Western Mediterranean Basin: Interpretation of Monitoring Data in Complex Coastal Terrain, J. Appl. Meteorol., 39, 487-508, 2000.

Monks, P. S.: A review of the observations and origins of the spring ozone maximum, Atmos. Environ., 34, 3545-356, 2000.

Monks, P. S., Granier, C., Fuzzi, S., Stohl, A., Williams, M. L., Akimoto, H., Amann, M., Baklanov, A., Baltensperger, U., Bey, I., Blake, N., Blake, R. S., Carslaw, K., Cooper, O. R., Dentener, F., Fowler, D., Fragkou, E., Frost, G. J., Generoso, S., Ginoux, P., Grewe, V., Guenther, A., Hansson, H. C., Henne, S., Hjorth, J., Hofzumahaus, A., Huntrieser, H., Isaksen, I. S. A., Jenkin, M. E., Kaiser, J., Kanakidou, M., Klimont, Z., Kulmala, M., Laj, P., Lawrence, M. G., Lee, J. D., Liousse, C., Maione, M., McFiggans, G., Metzger, A., Mieville, A., Moussiopoulos, N., Orlando, J. J., O’Dowd, C. D., Palmer, P. I., Parrish, D. D., Petzold, A., Platt, U., Pöschl, U., Prévôt, A. S. H., Reeves, C. E., Reimann, S., Rudich, Y., Sellegri, K., Steinbrecher, R., Simpson, D., ten Brink, H., Theloke, J., van der Werf, G. R., Vautard, R., Vestreng, V., Vlachokostas, Ch., and von Glasow, R.: Atmospheric composition change - global and regional air quality, Atmos. Environ., 43, 5268-5350, 2009.

Monks, P. S., Archibald, A. T., Colette, A., Cooper, O., Coyle, M., Derwent, R., Fowler, D., Granier, C., Law, K. S., Mills, G. E., Stevenson, D. S., Tarasova, O., Thouret, V., von Schneidemesser, E., Sommariva, R., Wild, O., and Williams, M. L.: Tropospheric ozone and its precursors from the urban to the global scale from air quality to short-lived climate forcer, Atmos. Chem. Phys., 15, 8889-8973, doi:10.5194/acp-15-8889-2015, 2015.

Myhre, G., Shindell, D., Bréon, F.-M., Collins, W., Fuglestvedt, J., Huang, J., Koch, D., Lamarque, J.-F., Lee, D., Mendoza, B., Nakajima, T., Robock, A., Stephens, G., Takemura, T., and Zhang, H.: Anthropogenic and Natural Radiative Forcing, in: Climate Change 2013: The Physical Science Basis, Contribution of Working Group I to the Fifth Assessment Report of the Intergovernmental Panel on Climate Change, edited by: Stocker, T. F., Qin, D., Plattner, G.-K., Tignor, M., Allen, S. K., Boschung, J., Nauels, A., Xia, Y., Bex, V., and Midgley, P. M., Cambridge University Press, Cambridge, UK, New York, NY, USA, 2013.

Neftel, A., Spirig, C., Prévôt, A. S. H., Furger, M., Stutz, J., Vogel, B., and Hjorth, J.: Sensitivity of photooxidant production in the Milan Basin: An overview of results from a EUROTRAC-2 Limitation of Oxidant Production field experiment, J. Geophys. Res., 107, 8188, doi:10.1029/2001JD001263, 2002.

Ordóñez, C., Mathis, H., Furger, M., Henne, S., Hüglin, C., Staehelin, J., and Prévôt, A. S. H.: Changes of daily surface ozone maxima in Switzerland in all seasons from 1992 to 2002 and discussion of summer 2003, Atmos. Chem. Phys., 5, 1187-1203, doi:10.5194/acp-5-1187-2005, 2005.

Otero, N., Sillmann, J., Schnell, J. L., Rust, H. W., and Butler, T.: Synoptic and meteorological drivers of extreme ozone concentrations over Europe, Environ. Res. Lett., 11, 024005, doi:10.1088/1748-9326/11/2/024005, 2016.

Pausata, F. S. R., Pozzoli, L., Vignati, E., and Dentener, F. J.: North Atlantic Oscillation and tropospheric ozone variability in Eu- rope: model analysis and measurements intercomparison, Atmos. Chem. Phys., 12, 6357-6376, doi:10.5194/acp-12-63572012, 2012.

Pfahl, S. and Wernli, H.: Quantifying the relevance of atmospheric blocking for co-located temperature extremes in the Northern Hemisphere on (sub-)daily time scales, Geophys. Res. Lett., 39, L12807, doi:10.1029/2012GL052261, 2012.

Richards, N. A. D., Arnold, S. R., Chipperfield, M. P., Miles, G., Rap, A., Siddans, R., Monks, S. A., and Hollaway, M. J.: The Mediterranean summertime ozone maximum: global emission sensitivities and radiative impacts, Atmos. Chem. Phys., 13, 2331-2345, doi:10.5194/acp-13-2331-2013, 2013.

Russo, A., Trigo, R. M., Martins, H., and Mendes, M. T.: $\mathrm{NO}_{2}$, $\mathrm{PM}_{10}$ and $\mathrm{O}_{3}$ urban concentrations and its association with circulation weather types in Portugal, Atmos. Environ., 89, 768-785, doi:10.1016/j.atmosenv.2014.02.010, 2014.

Santos, J. A., Andrade, C., Corte-Real, J., and Leite, S.: The role of large-scale eddies in the occurrence of winter precipitation deficits in Portugal, Int. J. Climatol., 29, 1493-1507, 2009a.

Santos, J. A., Pinto, J. G., and Ulbrich, U.: On the development of strong ridge episodes over the eastern North Atlantic, Geophys. Res. Lett., 36, L17804, doi:10.1029/2009GL039086, 2009 b.

Santos, J. A., Pfahl, S., Pinto, J. G., and Wernli, H.: Mechanisms underlying temperature extremes in Iberia: a Lagrangian perspective, Tellus A, 67, 26032, doi:10.3402/tellusa.v67.26032, 2015.

Scaife, A. A., Woolings, T., Knight, J., Martin, G., and Hinton, T.: Atmospheric Blocking and Mean Biases in Climate Models, J. Climate, 23, 6143-6152, doi:10.1175/2010JCLI3728.1, 2010.

Schnell, J. L., Holmes, C. D., Jangam, A., and Prather, M. J.: Skill in forecasting extreme ozone pollution episodes with a global atmospheric chemistry model, Atmos. Chem. Phys., 14, 77217739, doi:10.5194/acp-14-7721-2014, 2014.

Schnell, J. L., Prather, M. J., Josse, B., Naik, V., Horowitz, L. W., Cameron-Smith, P., Bergmann, D., Zeng, G., Plummer, D. A., Sudo, K., Nagashima, T., Shindell, D. T., Faluvegi, G., and Strode, S. A.: Use of North American and European air quality networks to evaluate global chemistry-climate modeling of surface ozone, Atmos. Chem. Phys., 15, 10581-10596, doi:10.5194/acp-15-10581-2015, 2015.

Seo, J., Youn, D., Kim, J. Y., and Lee, H.: Extensive spatiotemporal analyses of surface ozone and related meteorological variables in South Korea for the period 1999-2010, Atmos. Chem. Phys., 14, 6395-6415, doi:10.5194/acp-14-6395-2014, 2014.

Shen, L., Mickley, L. J., and Tai, A. P. K.: Influence of synoptic patterns on surface ozone variability over the eastern United States from 1980 to 2012, Atmos. Chem. Phys., 15, 10925-10938, doi:10.5194/acp-15-10925-2015, 2015.

Shepherd, T. G.: Atmospheric circulation as a source of uncertainty in climate change projections, Nat. Geosci., 7, 703-708, doi:10.1038/ngeo2253, 2014.

Sitch, S., Cox, P. M., Collins, W. J., and Huntingford, C.: Indirect radiative forcing of climate change through ozone effects on the land-carbon sink, Nature, 448, 791-794, doi:10.1038/nature06059, 2007.

Sousa, P. M., Trigo, R. M., Barriopedro, D., Soares, P. M. M., Ramos, A. M., and Liberato, M. L. R.: Responses of European precipitation distributions and regimes to different blocking locations, Clim. Dynam., 48, 1141-1160, doi:10.1007/s00382-0163132-5, 2016. 
Sousa, P. M., Trigo, R. M., Barriopedro, D., Soares, P. M. M., and Santos, J. A.: European temperature responses to blocking and ridge regional patterns, Clim. Dynam., submitted, 2017.

Steinbacher, M., Dommen, J., Ordóñez, C., Reimann, S., Grüebler, F. C., Staehelin, J., and Prévôt, A. S. H.: Volatile Organic Compounds in the Po Basin, Part A: Anthropogenic VOCs, J. Atmos. Chem., 51, 271-291, 2005.

Tarasova, O. A. and Karpetchko, A. Yu.: Accounting for local meteorological effects in the ozone time-series of Lovozero (Kola Peninsula), Atmos. Chem. Phys., 3, 941-949, doi:10.5194/acp3-941-2003, 2003.

Thielmann, A., Prévôt, A. S. H., and Staehelin, J.: Sensitivity of ozone production derived from field measurements in the Italian Po basin, J. Geophys. Res., 107, 8194, doi:10.1029/2000JD000119, 2002.

Trigo, R. M., Trigo, I. F., DaCamara, C. C., and Osborn, T. J.: Climate impact of the European winter blocking episodes from the NCEP/NCAR Reanalyses, Clim. Dynam., 23, 17-28, doi:10.1007/s00382-004-0410-4, 2004.

Vautard, R., Honoré, C., Beekmann, M., and Rouil, L.: Simulation of ozone during the August 2003 heat wave and emission control scenarios, Atmos. Environ., 39, 2957-2967, 2005.

Velchev, K., Cavalli, F., Hjorth, J., Marmer, E., Vignati, E., Dentener, F., and Raes, F.: Ozone over the Western Mediterranean Sea - results from two years of shipborne measurements, Atmos. Chem. Phys., 11, 675-688, doi:10.5194/acp-11-675-2011, 2011.
Vial, J. and Osborn, T.: Assessment of atmosphere-ocean general circulation model simulations of winter northern hemisphere atmospheric blocking, Clim. Dynam., 39, 95-112, 2012.

Von Storch, H. and Zwiers, F. W.: Statistical Analysis in Climate Research, Cambridge University Press, Cambridge, UK, 1999.

Wilks, D. S.: Statistical Methods in the Atmospheric Sciences, 3rd Edition, Academic Press, Oxford, UK, 2011.

Woollings, T., Pinto, J. G., and Santos, J. A.: Dynamical Evolution of North Atlantic Ridges and Poleward Jet Stream Displacements, J. Atmos. Sci., 68, 954-963, 2011.

Zanis, P., Hadjinicolaou, P., Pozzer, A., Tyrlis, E., Dafka, S., Mihalopoulos, N., and Lelieveld, J.: Summertime free-tropospheric ozone pool over the eastern Mediterranean/Middle East, Atmos. Chem. Phys., 14, 115-132, doi:10.5194/acp-14-115-2014, 2014.

Zappa, G., Masato, G., Shaffrey, L., Woollings, T., and Hodges, K.: Linking Northern Hemisphere blocking and storm track biases in the CMIP5 climate models, Geophys. Res. Lett., 41, 135-139, doi:10.1002/2013GL058480, 2014.

Zhang, Y. and Wang, Y.: Climate-driven ground-level ozone extreme in the fall over the Southeast United States, P. Natl. Acad. Sci. USA, 113, 10025-10030, doi:10.1073/pnas.1602563113, 2016. 